Summer 2008

\title{
Measuring Outcomes: Post-Graduation Measures of Success in the U.S. News \& World Report Law School Rankings
}

Andrew P. Morris

University of Illinois

William D. Henderson

Indiana University Maurer School of Law, wihender@indiana.edu

Follow this and additional works at: https://www.repository.law.indiana.edu/ilj

Part of the Education Law Commons, and the Legal Education Commons

\section{Recommended Citation}

Morris, Andrew P. and Henderson, William D. (2008) "Measuring Outcomes: Post-Graduation Measures of Success in the U.S. News \& World Report Law School Rankings," Indiana Law Journal: Vol. 83 : Iss. 3 , Article 2.

Available at: https://www.repository.law.indiana.edu/ilj/vol83/iss3/2

This Article is brought to you for free and open access by the Law School Journals at Digital Repository @ Maurer Law. It has been accepted for inclusion in Indiana Law Journal by an authorized editor of Digital Repository @ Maurer Law. For more information, please contact rvaughan@indiana.edu.

\section{$\Psi$}

JEROME HALL LAW LIBRARY

INDIANA UNIVERSITY

Maurer School of Law
Bloomington 


\title{
Measuring Outcomes: Post-Graduation Measures of Success in the U.S. News \& World Report Law School Rankings
}

\author{
ANDREW P. MORRISS * \& WILLIAM D. HENDERSON**
}

The U.S. News \& World Report annual rankings play a key role in ordering the market for legal education, and, by extension, the market for entry level lawyers. This Article explores the impact and evolution of placement and post-graduation data, which are important input variables that comprise twenty percent of the total rankings methodology. In general, we observe clear evidence that law schools are seeking to maximize each placement and post-graduation input variable. During the 1997 to 2006 time period, law schools in all four tiers posted large average gains in employment rates upon graduation and nine months, which appear to result from a combination of competition and gaming strategies. In addition, law schools in tiers 2, 3 , and 4 have increased $1 L$ academic attrition, which may be an attempt to increase the U.S. News bar passage score.

We also use multivariate regression analysis to model the employed at graduation and employed at nine months input variables. We find that the following factors are associated with higher employed at graduation rates: (1) higher 25th percentile Law School Admissions Test (LSAT) scores, (2) more on-campus interviews (OCI), (3) higher percentage of part-time students, (4) location outside a Top 10 corporate law market, and (5) status as a historically black law school. All of these factors except LSAT and OCI activity vanish when examining the employed at nine months data. The U.S. News Lawyer/Judge reputation score is associated with higher employment at nine months. Further research on the Lawyer/Judge survey instrument is needed.

After presenting our empirical results, we critique the specific measures of postgraduation success used in the U.S. News rankings and explain how each can be improved. We conclude that the best solution to law schools' complaints about the impact of U.S. News rankings is greater data availability and transparency, particularly on post-graduation outcomes and other factors affecting students' eventual employment prospects.

* H. Ross \& Helen Workman Professor of Law and Professor of Business, University of Illinois. A.B. Princeton University; J.D., M.P.Aff., University of Texas; Ph.D. (Economics) Massachusetts Institute of Technology. The authors would like to thank Jonathan Adler, Barbara Andelman, Ronald Cass, Russell Korobkin, Brian Leiter, Bob Morse, Richard Posner, and Sonia Winner for their helpful comments. In addition, we are grateful for the excellent research and data collection efforts of our research assistant, Jeremy Handschuh.

** Associate Professor, Indiana University School of Law-Bloomington. B.A. Case Western Reserve University; J.D., University of Chicago Law School. 


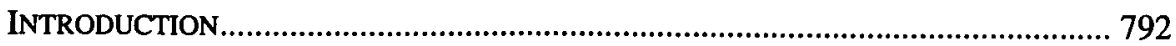

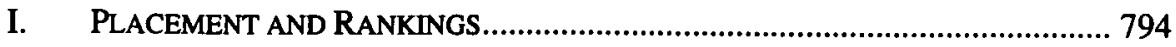

II. U.S. NEWS'S EVOLVING PLACEMENT METHODOLOGY ................................ 797

A. The Evolutionary Record from 1991 to 1996..................................... 797

B. Methodological Stability, 1997 to 2006............................................ 802

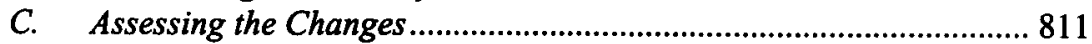

III. ANALYSIS OF POST-GRADUATION MEASURES.......................................... 813

A. Determinants of Employment Variables ........................................... 814

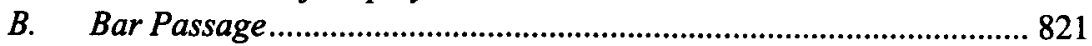

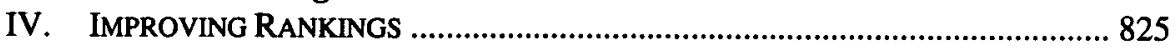

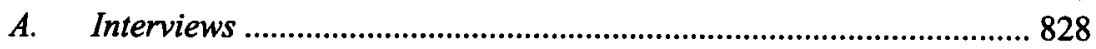

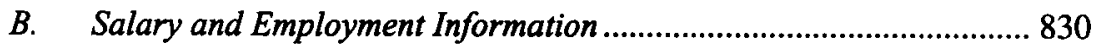

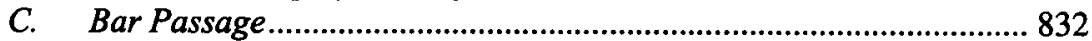

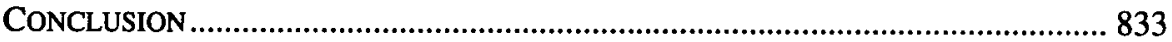

\section{INTRODUCTION}

Rankings matter. They may or may not measure educational quality, but they have a major impact on legal education. ${ }^{1}$ David Yellen, dean of Chicago's Loyola University School of Law, recently noted that "[a]lmost anytime you talk about major changes in law schools, you can't get too far from the impact of the U.S. News \& World Report ranking." 2 Students perceive them as important indicators of the value of their degrees. As an anonymous student at the University of Houston recently said, commenting on his school's decline in the rankings, "[w]hile our degrees might hold the same value in Houston, we want our degrees to have value in other places." ${ }^{3}$ In 2005-2006, deans resigned at four law schools that had suffered large rankings declines, giving rise to at least the suspicion that their schools' drop in the rankings played a role in their departures. ${ }^{4}$ The student bar association president at another school that fell

1. In general, we agree with Professor Russell Korobkin's theory that the U.S. News rankings are not a measure of educational quality. See Russell Korobkin, Harnessing the Positive Power of Rankings: A Response to Posner and Sunstein, 81 IND. L.J. 35, 40 (2006) (criticizing "the dominant paradigm that assumes rankings should reflect ... the quality of education offered by the institutions that are ranked"). Rather, as Korobkin observes, the rankings are primarily a market-clearing device that enables top law students and legal employers to identify each other, thus augmenting "employment opportunities and . . . longterm earning potential" for prospective law school applicants. Id. at $40-43$ (positing the primary purpose of the U.S. News rankings is to provide a signal to students and legal employers that coordinates the market for entry level lawyers). See also Russell Korobkin, In Praise of Law School Rankings: Solutions to Coordination and Collective Action Problems, 77 TEX. L. REV. 403, 407-14 (1998) (same).

2. Leigh Jones, Law Schools Mean Business: For-Profits Joined in New Approaches, NAT'L L.J., Apr. 17, 2006 at 17.

3. Mark Donald, Ranking Rift Hastens UH Dean's Resignation; News, TEx. LAw., Apr. 24,2006 , at $1,2$.

4. See id. at 1 (discussing resignation of University of Houston Law Center Dean Nancy Rapoport in spring 2006); Leigh Jones, Law Deans Feel the Heat from Rankings: Houston Law Center's Dean's Resignation is Latest Sign of Growing Pressure, NAT'L L.J., May 1, 2006, at 6. 
precipitously from the second tier to the fourth over the past five years compared law school performance in U.S. News to collegiate sports teams' performance on the field and pointedly observed that "one would be hard-pressed to suggest that poor rankings and a dismal national reputation would have little effect on the quality of athletes attracted to the university's sports teams." And, as one incoming dean noted, an important part of the dean's role is to "attend to the indices" used by U.S. News.

Law deans and law faculty regularly decry the U.S. News rankings for failing to capture the distinguishing features of their law schools and over-simplifying the comparison between schools. ${ }^{7}$ Rather than complain about the inappropriateness of comparative evaluations based on U.S. News's rankings' imperfections, we suggest that law schools should provide prospective students (and organizations considering rankings) with more data, to allow prospective students to make more informed choices. ${ }^{8}$ Indeed, we think law students would be best served by vigorous competition among alternative rankings systems that offer prospective students more opportunities to discover what they want to know. Such a system would enable students to consider questions like: "What are my likely employment options, expected earnings, and chances of passing the bar exam if I attend school X versus school Y?"9

5. Michelle S. Maxwell, 'The Rankings Game'-WVU's Neglect Harms Its Law School, Charleston Gazette, Apr. 21, 2006, at 5A.

6. Jones, supra note 4 (quoting Hiram Chodosh, incoming dean at the University of Utah S.J. Quinney School of Law). See also Gadi Dechter, UB's Next Law School Dean to Burnish School's Image: Closius, Former Dean at U. of Toledo, is Chosen From Among Twelve Candidates, BALT. SUN, Feb. 15, 2007 (reporting on the new law school dean at the University of Baltimore School of Law, who was hired based on his track record of bolstering the rankings at his former school).

7. See, e.g., Paul D. Carrington, On Ranking: A Response to Mitchell Berger, 53 J. LEGAL EDuC. 301, 301 (2003) (conceding that rankings supply "useful" information but quantification distorts and magnifies its relative importance); Nancy B. Rapoport, Ratings, Not Rankings: Why U.S. News \& World Report Shouldn't Want to Be Compared to Time and Newsweek-or The New Yorker, 60 OHIOST. L.J. 1097, 1099-1 100 (1999) (lamenting that "objective" input factors used by U.S. News rankings, such as GPA and LSAT scores, are not "good indicator[s] of quality" because "[t]hese numbers don't reflect how well the law school teaches, how cuttingedge its research is, or whether the law school community is cutthroat or supportive," among other relevant factors); Law School Admissions Council, Deans Speak Out, http://www.lsac.org/Choosing/deans-speak-out-rankings.asp [hereinafter Deans Speak Out] (letter that condemns the U.S. News rankings as "inherently flawed," endorsed by over 100 law school deans).

8. Although more information will neutralize the effects of U.S. News rankings, schools that unilaterally pursue this strategy can actually be made worse off. In other words, there is a massive collective action problem that hinders an effective response. See infra Part IV.

9. Although the post-graduation measures contribute only twenty percent of the overall score in U.S. News's system, post-graduation measures alone explain sixty-five percent of the variance of overall score of the 100 individually ranked schools in the $2003,2004,2005$, and 2006 rankings. One reviewer asked us whether or not a focus on outcomes ignored law schools' claim to be providing education. There may well be independent value to a legal education, but our sense from countless conversations with students is that the vast majority of law students enter law school with finding a law-related job as an important, if not the important, goal. 
Unlike the heavily criticized portions of the U.S. News rankings, such as the academic reputation survey ${ }^{10}$ or library spending, ${ }^{11}$ post-graduation measures are directly connected to graduates' future welfare and so are a legitimate basis for comparison. ${ }^{12}$ Our students are investing in their futures, with their money, their time, and by forgoing alternative opportunities. Therefore, we think law schools-or governing organizations, such as the American Bar Association and the Association of American Law Schools-should collect, aggregate, verify, and publish the data necessary to facilitate accurate and meaningful comparisons of various post-graduation outcomes. ${ }^{13}$ And in the ensuing competition, we think our students and future alumni will be made better off.

As a first step toward this goal, we carefully deconstruct and analyze several measures of post-graduation outcomes. Our study is organized in four parts. Part I discusses the economic relationships between rankings and placement. Part II describes the evolution of the U.S News post-graduation methodology and comments on the rationales for the extensive changes in the past fifteen years. Part III examines each of the various components of the post-graduation ranking and provides detailed empirical analysis of those for which data is available. Part IV suggests strategies schools might consider for improving their post-graduation performance in U.S. News, several ways U.S. News might improve its measures of post-graduation success, and discusses the influence of rankings on schools' efforts to improve their post-graduation performance. We conclude with some brief remarks on the implications of our findings for the rankings debate.

\section{Placement AND RANKINGS}

The U.S. News rankings are based on a composite score of several inputs that bear some theoretical relationship to law school quality. Over the last fifteen years, U.S. News has repeatedly revised the inputs included and how they are weighted. Notwithstanding this tinkering process, the resulting composite score consistently reflects four discrete categories of law school characteristics: (1) quality of enrolled students, including acceptance rates and median Law School Admissions Test (LSAT) scores and undergraduate grade point average (UGPA); (2) school reputations, controversially based on surveys of deans, professors, judges, and lawyers; (3) school

10. Cf. Brian Leiter's Law School Rankings, How Students Should Use This Information, http://www.leiterrankings.com/students/2003studentguide.shtml (noting the distinction between faculty and teaching quality that is not captured by surveys of academic reputation).

11. Library holdings account for $0.75 \%$ of a school's total composite score. Law Methodology, U.S. News and World Report, http://www.usnews.com/articles/education/bestgraduate-schools/2008/03/26/law-methodology.html.

12. We agree with other commentators, such as Brian Leiter, that numerical rankings that are composites of several different input variables are inherently misleading. $C f$. Brian Leiter, Commentary, How to Rank Law Schools, 81 IND. L.J. 47, 51 (2006) (noting that relevant factors "should be measured separately rather than aggregated on the basis of unprincipled and unrationializable [sic] schema. One can rank schools [on many factors, including 'job placement'] . . . but there is no way these criteria can be meaningfully amalgamated.").

13. We also think students would benefit from disclosure of other law school data, but this paper is focused on post-graduation outcomes. 
resources, such as expenditure per student, library holdings, and student-faculty ratios; and (4) post-graduation outcomes, including employment rates, interview statistics, and bar passage.

Since the extension of the U.S. News rankings in 1990 beyond the initial surveybased Top 20 lists published in 1987, the outcomes category has included some combination of various measures that affect post-graduation success, including at different times law firm interviews, bar passage rates, graduate employment levels, and median starting salaries. Although these indices generally comprise only twenty percent of a law school's total composite score, we believe that post-graduation outcomes are actually the key drivers behind the enrollment decisions of prospective students. In this Article we analyze (a) changes in post-graduation outcomes category over time, and (b) how these changes have affected the status and behavior of law schools.

Our primary claim is that prospective students, when they reference U.S. News rankings, are primarily interested in post-graduation outcomes (or perceptions of likely outcomes). As tuition increases much faster than starting salaries for most law graduates, ${ }^{14}$ prospective students need a mechanism to assess the risk inherent in different admissions offers. Similarly, because prospective employers increasingly rely upon U.S. News rankings in directing their recruitment efforts, ${ }^{15}$ students have a strong incentive to carefully weigh the marginal benefits of attending a higher or lower ranked law schools. For example, a student admitted to an elite national law school may willingly take on high levels of debt in exchange for a wide array of employment opportunities, ${ }^{16}$ including a virtual guarantee of employment with a prestigious legal employer. ${ }^{17}$ Similarly, a student with lower entering credentials-and thus more likely to attend a non-elite law school-may be more interested in a school's tuition ${ }^{18}$ or bar

14. Despite well-publicized "salary wars" in large legal markets, see, for example, Gina Passarella, First-Year Pay Up 250 Percent in 20 Years at Big Firms, Legal INTELLIGENCER, Mar. 7, 2006, over the last fifteen years, the cost of legal education has increased much faster than associate salaries. See Leigh Jones, Salary Raises Dwarfed by Law School Tuition Hikes, NAT'L L.J., Feb. 6, 2006 (reporting data from NALP showing that average private sector pay increased $60 \%$ between 1990 and 2005 while private school tuition increased by $130 \%$ and instate public school tuition increased $267 \%$ ).

15. For example, one of the leading attorney recruiting firms publishes an annual guide for evaluating transcripts, academic honors, and journal membership at schools ranked in the first tier of the U.S. News rankings. See BCG ATTORNEY SEARCH, ThE 2007 BCG ATTORNEY SEARCH GUIDE TO AMERICA'S TOP 50 LAW SCHOOLS (2006), available at http://www.bcgsearch.com/pdf/BCG_Law_Schoool_Guide_2007.pdf.

16. See RONIT DinOVITZER, BRYANT G. GARTH, RICHARD SANDER, JoYCE STERLING \& GITA Z. WILDER, AFTER THE JD: FIRST RESULTS OF A NATIONAL STUDY OF LEGAL CAREERS 75 tbl.10.3 (2004) [hereinafter AFTER THE JD] (documenting that graduates of Top 10 law schools, as measured by U.S. News, have the highest median debt), available at http://www.nalpfoundation.org/webmodules/articles/articlefiles/87-After_JD_2004_web.pdf.

17. Empirical studies on this topic are readily accessible to prospective law students. See, e.g., Brian Leiter's Law School Rankings, The Most National Law School Based on Job Placement in Elite Law Firms, 2003), www.leiterrankings.com/jobs/2003job_national.shtml; Michael Sullivan, Law School Job Placement, www.calvin.edu/admin/csr/students/sullivan/law/ (updating Leiter's 2003 study).

18. See, e.g., William D. Henderson \& Andrew P. Morriss, Student Quality as Measured by 
passage statistics. ${ }^{19}$ In other words, students are not evaluating educational quality so much as return on investment. ${ }^{20}$

Rankings and employment prospects, however, are far from perfectly correlated. In our earlier empirical work on rankings, we observed strong evidence that both law students and legal employers depart from the rankings when it is economically beneficial for them to do so. ${ }^{21}$ Specifically, for approximately the bottom threequarters of the law school hierarchy, our statistical analysis suggested that students are engaged in a calculation that asks whether a marginally higher U.S. News ranking is worth higher tuition. ${ }^{22}$ Similarly, students with marginally higher entering credentials sometimes favor lower-ranked schools in thriving legal markets, presumably because these schools garner a disproportionate number of on-campus interviews from nearby corporate law firms. ${ }^{23}$ We now turn to an examination of how the post-graduation component of U.S. News's rankings has evolved over time.

LSAT Scores: Migration Patterns in the U.S. News Rankings Era, 81 IND. L.J. 163, 187-88 (2006) (presenting regression results based on bottom three quartiles of the U.S. News rankings that showed a statistically significant relationship between various cost factors, such as tuition, student debt, and status as a public law school, and change in a law school's median LSAT score over a twelve year period); Alex M. Johnson, Jr., The Destruction of the Holistic Approach to Admissions: The Pernicious Effects of Rankings, 81 IND. L.J. 309, 347 n.141 (2006) (law school dean noting that students admitted to more than one law school will make their enrollment decision based on several factors, including "the financial aid or scholarship package offered").

19. See, e.g., Melissa Nann, Over Seventy Percent Passed July Bar, Examiners Report Temple Raises Success Rate for Test Makers, LEGAL INTELLIGENCER, Oct. 17, 2003 (quoting the dean of Penn State Dickinson School of Law that "bar exam passing rates are something prospective students look at when they screen law schools" and that a recent forty-six percent rise in applicants is attributable "in part to the school's rising bar scores").

20. In a recent article on employer placement, a law student bluntly lays out the calculus: While some applicants may place a very high premium on diversity, many others may not care at all. The overwhelming majority of applicants, however, will place a very high value on career placement and cost of attendance. A legal education is not cheap. Debt of $\$ 80,000$ or more is typical . . . Naturally, one would expect prospective law students to weigh the monetary costs of attendance-tuition, fees, opportunity cost-against the benefits of expected future earnings and increased job prestige.

Anthony Ciolli, The Legal Employment Market: Determinants of Elite Firm Placement and How Law Schools Stack Up, 45 JURIMETRICS 413, 414 (2005).

21. See Henderson \& Morriss, supra note 18, at 193. See also Paul Oyer \& Scott Schaefer, Personnel-Economic Geography: Evidence from Large U.S. Law Firms 31 (Stanford Bus. Sch. Working Paper, June 29, 2007) (reporting on the importance of geographic proximity rather than law school rank in explaining concentration of educational credentials in a particular law firm office), available at http://faculty-gsb.stanford.edu/oyer/wp/lawyers.pdf.

22. See Henderson \& Morriss, supra note 18, at 187-88 (using multivariate regression analysis to explore changing LSAT medians among law schools and observing statistically significant increases for law schools in the bottom three U.S. News quartiles that charged lower tuition or saddled students with less debt).

23. See id. at 188-90 (using multivariable regression to show that change in the number of Am Law lawyers in a region is a strong predictor of gains in median LSAT scores for local law schools and further corroborating results by showing that the number of on-campus interviews by Am Law 200 firms is a function of the number of firms located in the local market). We think these data suggest that students prefer schools in larger and more prosperous legal 


\section{U.S. NEWS'S Evolving PlaCeMENT METHOdology}

Since the inception of detailed rankings in 1991, various indices of post-graduation success have comprised twenty percent of the total input variables that produce the overall U.S. News rankings. Within the twenty percent, however, the post-graduation methodology has undergone considerable evolution, as shown in Table 1.

Part II chronicles and analyzes the significance of these changes. It covers three interrelated topics. Section A discusses the 1991 to 1996 time period, when annual changes in methodology produced some relatively large yearly fluctuations in the overall U.S. News rankings. Nonetheless, outcome data increasingly mirrored the winners in the overall rankings. Section $B$ examines the market dynamics and equilibrium that emerge as the post-graduation measures remained unchanged from 1997 to 2005 . Finally, Section C characterizes the nature of the methodology changes, speculates about the likely motivations of U.S. News editors in making the changes, and addresses the impact the changes had on law school competition.

Table 1. U.S. News Inputs and Weights for Post-Graduation Success

\begin{tabular}{|c|c|c|c|c|c|c|c|c|c|c|}
\hline \multirow[b]{2}{*}{ Year } & \multirow{2}{*}{ 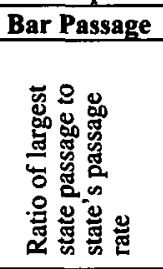 } & \multicolumn{4}{|c|}{ Percent Employed } & \multicolumn{3}{|c|}{ Employer Interviews } & \multicolumn{2}{|c|}{ Starting Salary } \\
\hline & & 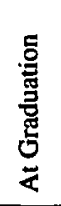 & 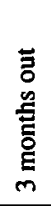 & 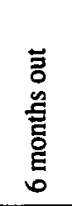 & 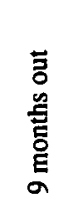 & 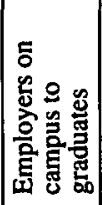 & 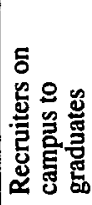 & 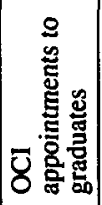 & 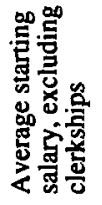 & 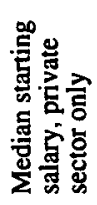 \\
\hline 1991 & -- & $5 \%$ & $5 \%$ & -- & - & $5 \%$ & - & -- & $5 \%$ & -- \\
\hline 1992 & - & $5 \%$ & -- & $5 \%$ & -- & -- & $5 \%$ & -- & $5 \%$ & -- \\
\hline 1993 & -- & $8 \%$ & - & $6 \%$ & - & -- & $1 \%$ & -- & $5 \%$ & - \\
\hline 1994 & -- & $6 \%$ & -- & $8 \%$ & -- & - & $1 \%$ & -- & -- & $5 \%$ \\
\hline 1995 & - & $6 \%$ & -- & $11 \%$ & - & -- & - & $1 \%$ & - & $2 \%$ \\
\hline 1996 & -- & $6 \%$ & -- & $12 \%$ & -- & -- & - & - & - & $2 \%$ \\
\hline $1997-2005$ & $2 \%$ & $6 \%$ & -- & -- & $12 \%$ & - & - & - & -- & -- \\
\hline 2006 & $2 \%$ & $4 \%$ & -- & -- & $14 \%$ & -- & - & $-\cdot$ &.- & - \\
\hline
\end{tabular}

\section{A. The Evolutionary Record from 1991 to 1996}

U.S. News's 1991 expansion beyond its initial survey-based methodology included four measures of placement success: "the percentage of 1990 graduates employed at graduation; the percentage employed three months after graduation; the ratio of the number of 1990 graduates to the number of employers recruiting on campus during the past academic year; and average starting salary (excluding bonuses and judicial clerkships) for the 1990 class." ${ }^{24}$ These factors accounted for twenty percent of the

markets, although students may also be choosing a school where they believe they will achieve a higher class rank over a higher ranked school, on the theory that this will give them an advantage in the job market.

24. Top 25 Law Schools, U.S. News \& World ReP., Apr. 29, 1991, at 74. 
total score, with each component being ranked and the ranks combined and scaled into a final score. ${ }^{25}$ Only the Top 25 schools were listed in the magazine in 1991. Approximately half the schools did better on placement than they did overall, thus suggesting a relatively weak connection-at least in the early $1990 \mathrm{~s}$-between rank and the entry level market for lawyers. ${ }^{26}$

The big winners on placement in this first ranking (scoring seven places or higher on placement than they did overall) were Cornell (thirteenth overall, sixth on placement) and Northwestern (fourteenth overall, seventh on placement). ${ }^{27}$ The big losers, scoring ten points or more below their overall rank on placement, were Stanford (ranked fourth overall, seventeenth on placement); Georgetown (ranked eleventh overall, twenty-second on placement); Minnesota (ranked twenty-second overall, fortythird on placement); and UNC (ranked twenty-fourth overall, thirty-fifth on placement). Both Stanford's and Minnesota's poor performance on placement were attributable in part to their failure to provide U.S. News with sufficient information, forcing the magazine to estimate numbers. These estimates put both schools substantially below their scores on other criteria and likely dropped them in the overall rankings. ${ }^{28}$

In 1992, the rankings expanded to provide "quartile" information for schools outside the Top 25, along with a subset of the detailed information for the non-Top 25 schools. ${ }^{29}$ The placement score was derived from the same subfactors as in 1991 with one exception: the employed at three months statistic was changed to employed at six

25. Id. at 74-75.

26. In addition, schools were not as focused on their U.S. News rankings during the earlier years and so may have not put as much effort into gathering the requisite input data.

27. U.S. NEWS \& WORLD REP., supra note 24. Cornell and Northwestern might well have fallen below Texas (ranked fifteenth overall, sixteenth on placement) had they not done so well on placement, for Texas beat Cornell on two of the other four metrics and tied with Cornell on one of the other four and beat Northwestern on one of the other four and tied with Northwestern on one of the other four. Certainly had Northwestern beaten Cornell on placement rank, it would have traded places with Cornell in the overall rankings, since their total scores were separated only by 0.8 points.

28. Had Stanford received a placement ranking commensurate with its other rankings, it likely would have been ranked third instead of fourth, beating Chicago, since Stanford ranked higher than Chicago on three of five components (Lawyer/Judge reputation third versus seventh; Student Selectivity, third versus sixth; Faculty Resources, second versus third), tied with Chicago on one (Academic, both ranked first) and behind Chicago only on Placement (seventeenth versus first). It is not clear whether Stanford could have beaten Harvard for number two, since it beat Harvard on one ranking (Faculty Resources, second versus sixth) and tied on one (Academic Reputation, both first) but lost to Harvard on two (Student Selectivity, third versus first, and Lawyer/Judge Reputation, third versus first) in addition to losing on Placement (seventeenth versus fifth). Had Minnesota received a placement ranking commensurate with its other rankings, it likely would have been ranked several ranks higher, since with a better placement score, it might have beaten George Washington (which Minnesota outranked on two of the other four criteria by fairly wide margins, losing on the other two by narrower margins) with whom it tied for overall rank twenty-second and Wisconsin (twentyfirst) (Minnesota beat on four of four of the other criteria) and Hastings (twentieth) (Minnesota beat on three of four of the other criteria) and possibly even challenged Iowa (nineteenth) (Minnesota beat on two of four of the other criteria).

29. Best of the Rest, U.S. NEws \& WORLD REP., Mar. 23, 1992, at 80. 
months. ${ }^{30}$ This time both Stanford and Minnesota provided data to the magazine, and both did substantially better on placement than they had the previous year based on U.S. News's estimates: Stanford jumped twelve places in placement ranking (and one place overall) and Minnesota jumped nine places in placement ranking (and one place overall). Whether consciously adopted or not, the low-ball estimation method used in 1991 provided an incentive for schools to cooperate with the magazine's data requests. $^{31}$

The placement scores for 1992 also exhibited a lot of variation from 1991. Eleven of the twenty-three schools repeating in the Top 25 dropped in placement rank, ten improved, and only two had the same rank in 1991 and 1992. U.S. News also changed the overall weighting for faculty resources and student selectivity; as a result, changes in overall rank were only loosely correlated with changes in placement score (eight schools' overall ranks moved in the same direction as their placement rank; four moved in opposite directions). The most variable component of the placement score was salary information, with ten schools reporting drops, including two schools with substantial drops in average starting salaries (Minnesota (11\%), Texas (8\%)).

Careful inspection of the data from 1992 suggests that much of the movement was due to significant differences in the quality of data collection. For example, fifteen schools of 1991's Top 25 reported increases in salary information in 1992, including some hefty nominal increases (Hastings (15\%), George Washington (9\%), Wisconsin $(9 \%)$, Notre Dame $(7 \%)$ ). Because regional salary variations of this magnitude were unlikely, and the job market for lawyers was particularly bleak during this time period, ${ }^{32}$ it is possible that salary fluctuations could have been a function of the number of graduating students providing information. Indeed, if unemployed graduates were less likely to provide the school with salary information, the missing data could actually have improved a school's overall U.S. News ranking.

In 1993, U.S. News kept the same post-graduation components but substantially altered the weights of the placement score. ${ }^{33}$ Employed at graduation became $40 \%$ of the placement score ( $8 \%$ of the total), employed at six months became $30 \%$ of the placement score ( $6 \%$ of the total), the interview/graduate ratio dropped to $5 \%$ of the score (1\% of the total); and average starting salary rose to $25 \%$ of the placement score ( $5 \%$ of the total). ${ }^{34}$ Despite these changes, there was little movement in the Top 25: the top five schools did not change at all and only nine of the remaining schools changed places. Most of the Top 25 had placement scores below (and sometimes well below)

30. See Law Schools: The Top 25, U.S. NEws \& WoRLD REP., Mar. 23, 1992, at 78.

31. The editors at U.S. News eventually noticed these incentives and altered the methodology. See infra notes $37-41$ and accompanying text.

32. Law firms and law schools reported much lower recruitment activity in the early 1990 s than the late 1980s. See, e.g., Claudia MacLachlan, Another Paltry Summer, the Largest Firms Offer Even Fewer Jobs, NAT'L L.J., Jun. 8, 1992, at 1 (discussing lower rates of OCI activity in 1991 than in 1990 and noting the trend toward smaller summer programs among several larger firms); Ken Myers, New Placement Survey Confirms Just How Bleak Job Market Is, NAT'L L.J., May 4, 1992, at 4 (discussing a report by NALP that found "fewer on-campus interviews, few job offers-both for summer associate positions and for full-time employment-and few graduates with jobs six months after graduation").

33. Note, however, that the total contribution of the score remained at twenty percent.

34. The "A" List: The Top 25, U.S. News \& WORLD REP., Mar. 22, 1993, at 62, 62-63. 
their overall ranks, and only three beat their overall rank in placement: Boston College (up eleven), USC (up four), and NYU (up five). The Top 25 schools hurt most by placement included Georgetown (down seven), Texas (down six), Notre Dame (down nine), Hastings (down forty-one), lowa (down eighteen), and Minnesota (down thirtyfour). Four of these (not Georgetown and Hastings) may have been hampered by locations far from the main legal job markets, suggesting the importance of location for boosting components like interview/graduate ratio. ${ }^{35}$ The ranking expanded to the Top 50 in 1994 and placement weights changed slightly, again shifting emphasis to placement six months after graduation (increased to $40 \%, 8 \%$ overall) from placement at graduation (reduced to $30 \%, 6 \%$ overall). ${ }^{36}$

One of the most important changes in employment methodology occurred in 1995. In prior years, U.S. News assumed that graduates not reporting their status to schools were employed. Beginning in 1995, the editors assumed that only $25 \%$ of those graduates with unknown status were employed. ${ }^{37}$ As U.S. News noted, the prior method had favored "schools with low reporting rates." any reason to suspect that a particular graduate was unemployed, there had been no incentive to confirm the graduate's status prior to the 1995 edition. ${ }^{39}$ The new method encouraged schools to confirm graduates' statuses and improved the quality of information. Other changes in 1995 included: additional weight on employed after graduation (employed at six months rising to $55 \%$ of placement, $11 \%$ overall); starting salary (now measured as a median) falling to $10 \%$ of placement ( $2 \%$ overall), ${ }^{40}$ and an alteration in the interview statistic from the ratio of on-campus interviewers to graduates to the ratio of on-campus interview appointments to graduates. ${ }^{41}$

Although there was little movement among the top schools from 1994 to 1995 , the top nine schools were, unlike prior years, the top nine in placement (albeit in a different order from their overall ranking). This stabilization could have been influenced by a combination of or one of two factors: (1) the publication of placement data had pushed law schools to improve their placement efforts and/or reporting; and (2) entering law students and employers were increasingly relying upon U.S. News to make enrollment and hiring decisions. ${ }^{42}$ The biggest winners (losers) overall were also all among the biggest winners (losers) in placement: Virginia's overall rank fell six places and four in placement; Minnesota rose eight places overall and thirty-eight in placement; Iowa rose four places overall and fourteen in placement; Hastings rose

35. Our findings in Part III.A, infra, suggest that employment rates for some schools are negatively affected by location in a large legal market. We theorized that this is due to an influx of résumés for students at higher ranked schools outside the region. See Henderson \& Morriss, supra note 18, at 188-90 \& tbl.7 (providing a discussion and data on the relationship between geography and law firm interviews).

36. Methodology, U.S. NEWS \& WORLD REP., Mar. 21, 1994, at 72, 73.

37. Disturbing Discrepancies, U.S. NEWS \& WORLD REP., Mar. 20, 1995, at 82.

38. Id.

39. In addition, unemployed graduates might well have been more likely to be disaffected than employed graduates and so less likely to report their status to their school.

40. Methodology, U.S. NEWS \& WORLD REP., Mar. 20, 1995, at 85.

41. Id.

42. In essence, the availability of information via U.S. News permitted the coordination function of rankings described by Professor Korobkin. See Korobkin, In Praise Of Law School Rankings, supra note 1. 
three places overall and forty in placement; Texas fell six places overall and fifteen in placement. The apparent increasing effort at placement also meant that the few schools that suffered reverses were more likely to suffer in the overall ranking than in prior years. Primed by the pump of better and more accurate information, the ranking of student employment prospects began to mirror more closely a law school's overall ranking.

By 1995 , it was obvious to all law schools that U.S. News rankings defined the law school hierarchy and that even small differences in rankings were affecting the perceptions of entering students, legal employers, and alumni. The heightened stakes in turn created greater incentives to fudge key input variables. In a short story that accompanied the 1995 rankings, the U.S. News editors consulted with a law firm compensation specialist, who reported that the salary figures for recent graduates "seem a bit high." ${ }^{43}$ Indeed, the correlation between salaries figures for 1994 and 1995 was a mere $0.359,,^{44}$ suggesting either a wildly erratic labor market or, what we think is more likely, systemic manipulation of a key input variable by individual law schools. The editors also reported "disturbing discrepancies" between the LSAT numbers reported to the ABA and those reported to the magazine, naming twenty-seven schools that had higher numbers reported to the magazine than in their ABA reports. ${ }^{45}$ With an eye toward improving the integrity of its rankings, the story concluded, "Will the ABA eventually insist that schools make such data public? Leaders of the group are expected to decide that crucial question for both admissions and placement numbers later this year." 46

The 1996 edition dropped the interview numbers entirely and again boosted the importance of the six-month employment statistics ( $60 \%$ of placement, $12 \%$ overall) ${ }^{47}$ The big winners in post-graduation numbers were Washington, Michigan, and UCLA. Overall, the volatility that characterized the first few years of the U.S. News rankings was gradually starting to dissipate.

In 1997, the ABA published a new law school guide that provided detailed information in a uniform format on each $\mathrm{ABA}$-approved law school, ${ }^{48}$ albeit not in

43. Disturbing Discrepancies, supra note 37, at 82 (quoting Ward Bower of Altman Weil Pensa, Inc.).

44. Authors' calculations. In contrast, the correlation between 1992 and 1993 was a much more plausible 0.872 .

45. Disturbing Discrepancies, supra note 37, at 82 . The schools (and discrepancies) were Alabama (four); Detroit Mercy (four); Duquesne (three); Golden Gate (three); SUNY at Buffalo (three); Whittier (three); Creighton (two); Indiana (Indianapolis) (two); Mississippi College (two); Pace (two); Stetson (two); Akron (one); Boston University (one); Catholic (one); Cumberland-Samford (one); Hawaii (one); lowa (one); Louisiana State (one); Loyola at L.A. (one); Miami (one); New England (one); Pennsylvania (one); Pittsburgh (one); San Francisco (one); Santa Clara (one); Washington and Lee (one); and Washington University (one). Id.

46. Id.

47. See Press Release, U.S. News \& WoRLd ReP., Methodology (Mar. 18, 1996).

48. See Chris Klein, Stats Change, But Very Little Differs in Magazine's Ranking, NAT'L L.J., Mar. 10, 1997, at A13 (noting that the "methodological changes were spurred by statistics culled from a new, detailed ABA survey of law schools and their operations"). The survey, which is now published annually, was compiled by the Office of the Consultant on Legal Education for the American Bar Association. See ABA-APPRoved LAw Schools (Rick L. Morgan \& Kurt Snyder, eds., 1997). 
format that facilitated (or encouraged) school-to-school comparisons. ${ }^{49}$ The availability of this information-and its presumed greater veracity, since it was submitted to the body that accredits individual law schools-prompted U.S. News to drop the salary information and replace it with a variable based on first-time bar passage rate. ${ }^{50}$ The magazine also changed the post-graduation employment measure from six months to nine months after graduation. ${ }^{51}$ This boosted numbers for almost every school, with only a few schools reporting lower numbers than the prior year's six month statistics, a possible impact of the new ABA reporting requirements. Yet, despite these changes in methodology, there was virtually no change in the Top 25 rankings.

Arguably, the annual publication of U.S. News rankings for six years effectively coordinated the behavior of law schools, law school applicants, and legal employers. ${ }^{52}$ Since the most recent rankings were the best predictor of an applicant's eventual desirability on the job, enrollment decisions by applicants increasingly became a function of a law school's U.S. News rank. Further, law schools were responding to overall rankings pressures by adopting admissions practices that relied more heavily on LSAT and UGPA. ${ }^{53}$ Hence, a relatively stable equilibrium began to emerge.

\section{B. Methodological Stability, 1997 to 2006}

With the exception of some minor reweighing of employment data in $2006,{ }^{54}$ the U.S. News post-graduation methodology has remained the same for nearly a decade, as shown in.Table $1 .{ }^{55}$ During this time period, the $20 \%$ post-graduation consisted of two

49. The data were reported school-by-school, with no tables facilitating comparison.

50. The new bar passage variable was calculated as follows: [first-time bar passage rate in the state where the largest number of graduates took the bar] divided by [that state's overall first-time bar passage]. See Press Release, U.S. NEws \& WORLD REP., Methodology (Mar. 10, 1997).

51. Id.

52. In other words, the 1991 to 1996 time period strongly corroborates the market coordinate theory of Russell Korobkin. See Korobkin, In Praise of Law School Rankings, supra note 1 and accompanying text.

53. In the current rankings-obsessed environment, it is hard for most readers to fathom how peripheral the LSAT was to most admission decisions during the 1950s and 60s. See, e.g., Patricia W. Lunneborg \& Donna Radford, The LSAT: A Survey of Actual Practice, 18 J. LEGAL EDUC. 313, 314 (1966) (reporting the results of a survey of admissions practices by eighty-eight law schools and reporting that only one school weighted the LSAT more than UGPA and that overall, "there is widespread distrust of formulae and a visible shrinking away from the spectre of automated admissions.... [Despite strong evidence of the LSAT's efficacy in predicting $1 \mathrm{~L}$ performance, the] arguments for more rigorous and systematic evaluation have not convinced [the] jury.").

54. In 2006, U.S. News reduced the weight given to employment at graduation (from $6 \%$ to $4 \%$ ) and increased that given to employed at nine months (from $12 \%$ to $14 \%$ ). See supra Table 1, p. 7.

55. See, e.g., Methodology, U.S. NEwS \& WoRLD REP., Mar. 2, 1998, at 81; Methodology, U.S. NEWS \& WORLD REP., Apr. 10, 2000 at 74; Methodology, U.S. NEWS \& WORLD REP., Apr. 9,2001 , at 79; Methodology, U.S. NEWS \& WORLD REP., (2002) at 61; Methodology, U.S. NEWs \& WORLD REPORT (2005) at 61 . 
principal inputs: employment (at graduation and nine months thereafter (18\% combined)) and bar passage (2\%). In contrast to the 1991 to 1996 period, when data collection practices and changes in methodology often produced significant shifts in individual law school rankings, the methodological stability of the 1997 to 2006 time period has been accompanied by significantly less movement in ordinal rankings.

During this period of relative calm, two trends are noteworthy: (1) mean employment statistics improved for virtually all ABA-approved law schools; and (2) more prestigious law schools distanced themselves from their lower-ranked competitors in bar passage statistics. This Section examines in detail the employment and bar passage trends.

\section{Employment at Graduation and at Nine Months}

If we believe employment data provided by law schools to the ABA and U.S. News (and there are good reasons, discussed below, to doubt them), the job prospects of law school graduates have improved enormously over the last decade. Based on our calculations from U.S. News input data, weighted by entering class size, the proportion of graduates from ABA-approved law schools who are employed at graduation has increased from $62.6 \%$ for the class of 1997 (used in 1999 rankings) to $73.9 \%$ for the class of 2004 (used in 2006 rankings). Similarly, the proportion of new lawyers employed within nine months of graduation has increased from $83.9 \%$ in 1995 (used in 1997 rankings) to $91.6 \%$ in 2004 (used in 2006 rankings). Moreover, as shown in Table 2, large gains were posted by law schools throughout the U.S. News hierarchy.

Table 2. Mean U.S. News Employment Inputs, by 1997 U.S. News Rank

\begin{tabular}{|c|c|c|c|c|c|c|}
\hline \multirow{2}{*}{$\begin{array}{c}1997 \text { U.S. News } \\
\text { Rank } \\
\end{array}$} & \multicolumn{3}{|c|}{ Employed at Graduation } & \multicolumn{3}{|c|}{ Employed at Nine Months } \\
\hline & 1999 & 2006 & Change & 1997 & 2006 & Change \\
\hline Top $16^{56}$ & $88.8 \%$ & $96.5 \%$ & +7.7 & $95.6 \%$ & $99.1 \%$ & +3.5 \\
\hline Rest of Tier 1 & $67.2 \%$ & $78.5 \%$ & +11.3 & $90.2 \%$ & $95.9 \%$ & +5.7 \\
\hline Tier 2 & $56.1 \%$ & $72.2 \%$ & +16.1 & $86.9 \%$ & $94.1 \%$ & +7.2 \\
\hline Tier 3 & $54.0 \%$ & $66.8 \%$ & +12.8 & $84.7 \%$ & $90.9 \%$ & +6.2 \\
\hline Tier 4 & $47.5 \%$ & $55.3 \%$ & +7.9 & $75.0 \%$ & $84.6 \%$ & +9.6 \\
\hline All Schools & $62.6 \%$ & $73.9 \%$ & +11.3 & $83.9 \%$ & $91.6 \%$ & +7.7 \\
\hline
\end{tabular}

The impressive surge in post-graduation employment could be explained either by healthy competition or by cynical manipulation by law schools. The optimistic story is that law schools, exposed to the competitive forces via U.S. News, dramatically improved their data collection and placement efforts. Certainly, there is strong

56. Note that we divide the fifty highest ranked law schools into "Top 16" and "Rest of Tier 1" because all of these schools have maintained their Top 16 status since the inception of the U.S. News rankings. See Richard Schmalbeck, The Durability of Law School Reputation, 48 J. LEGAL EDUC. 568, $572(1998)$ (noting that "the same sixteen schools have occupied the top sixteen spots in every survey" since 1990). 
evidence that U.S. News has spurred many schools to aggressively track their graduates. $^{57}$

The pessimistic-and we believe, more likely —explanation for the surge in postgraduation employment numbers is that some law schools aggressively mischaracterize (or artificially inflate) the employment status of their graduates. For example, at least some of the gains in post-graduation employment have been the product of short-term internships provided by law schools to their recent graduates in order to boost employment statistics for U.S. News purposes. ${ }^{58}$ Some is due to clever survey techniques designed to maximize employment numbers rather than actual improvements in employment. ${ }^{59}$ Further, post-graduation employment for U.S. News purposes does not require a law school to distinguish between legal employment that requires a law degree and non-legal jobs that are taken out of necessity to pay for living expenses.

The biggest cause for skepticism, however, is the sharp divergence between employment statistics and bar passage rates. At the same time that employment nine months after graduation climbed from $83.9 \%$ to $91.5 \%$, the overall first-time bar passage rate for this same cohort declined from $83.0 \%$ (1995) to $78.6 \%$ (2004). ${ }^{60}$ Since results from a second bar exam are unlikely to be available nine months after graduation, it is likely that much of the increased post-graduation employment reported to U.S. News is in jobs that do not require a valid license to practice law and hence are unlikely to pay a premium for three years of legal education. At a minimum, this practice has the potential to seriously mislead prospective law students attempting to

57. See, e.g., Leigh Jones, Law Schools Play the Rankings Game, NAT'L L.J., Apr. 18, 2005 , at 1,1 (noting that "[o]ne relatively easy way to move up [in the law school rankings] is by more closely tracking students' job placements after graduation" because of the way the U.S. News methodology treats incomplete data and citing several examples of law schools who now more closely and methodically monitor these numbers).

58. See Alex Wellen, The $\$ 8.78$ Million Maneuver, N.Y. TimEs, July 31,2005 , 4A, at 18 (reporting examples of two schools that utilize short term internships to boost the employment numbers reported to U.S. News); Dale Whitman, Doing the Right Thing, AALS NEWSLETTER, Apr. 2002, available at http://www.aals.org/presidentsmessages/pmapr02.html (citing an example of a law school that hired unemployed graduates to work in its library in order to boost its employed at nine months statistics).

59. See Richard A. Matasar, Ya Gotta Pay the Pig, 37 U. Tol. L. REv. 109, 112 (2005) (reporting how law schools boost their placement rates by employing graduates upon and shortly after graduation "or, calling graduates, and leaving them messages that if they do not call back, you will assume that they are employed").

60. The 1995 and 2004 bar passage rates were utilized by U.S. News for the rankings published in the springs of 1997 and 2006, respectively. The figures reported in the text were averages that weighed each school's full-time and part-time entering classes. According to data from the National Conference of Bar Examiners Web site, the overall bar passage rates followed a similar trend: $69.8 \%$ in 1995 , dropping to $63.6 \%$ in 2004 . National Conference of Bar Examiners, Bar Admission Statistics, http://www.ncbex.org/bar-admissions/stats/. This gives us some confidence despite the obvious dangers of attempting to reverse engineer bar passage rates for schools, since the U.S. News numbers report only the bar passage rate in the state where the largest number take the bar. See supra note 50 . These data are exactly the sorts of information law schools ought to be reporting in detail: bar passage statistics adjusted for LSAT and UGPA information, to allow prospective students to predict their own potential for success on the bar based on their credentials. 
evaluate the relative costs and benefits of a legal education. It is also hard to believe that this type of reporting should be considered sufficient to satisfy ABA Accreditation Standard 509, which requires a law school to provide "basic consumer information" in a "fair and accurate manner reflective of actual practice."

\section{Bar Passage}

In contrast to post-graduation employment statistics, which steadily increased between 1997 and 2006, there was significant variation in the U.S. News bar passage scores. ${ }^{62}$ As shown in Table 3, since U.S. News implemented bar passages as part of its placement methodology, the scores of higher and lower ranked schools have generally moved in opposite directions.

Table 3. Change in U.S. News Bar Score 1997-2006, by Starting Position

\begin{tabular}{|l|r|r|r|r|l|}
\hline \multicolumn{1}{|c|}{ 1997 Rank } & \multicolumn{1}{c|}{ Median } & \multicolumn{1}{c|}{ Mean } & \multicolumn{1}{c|}{ S.E. Mean } & \multicolumn{1}{c|}{ Std. Dev. } & \multicolumn{1}{c|}{ Valid N } \\
\hline \hline Top 16 & 0.077 & 0.094 & 0.017 & 0.067 & $\mathrm{~N}=16$ \\
\hline Rest of Tier 1 & 0.025 & 0.044 & 0.011 & 0.064 & $\mathrm{~N}=33$ \\
\hline Tier 2 & 0.019 & 0.035 & 0.015 & 0.092 & $\mathrm{~N}=38$ \\
\hline Tier 3 & -0.022 & -0.038 & 0.016 & 0.104 & $\mathrm{~N}=43$ \\
\hline Tier 4 & -0.057 & -0.041 & 0.022 & 0.140 & $\mathrm{~N}=42$ \\
\hline
\end{tabular}

The most likely explanation for these bar passage trends is a parallel process of credentials stratification within the law school hierarchy. ${ }^{63}$ Indeed, there is substantial evidence that each year's rankings influence the preferences of law school applicants (possibly with an eye toward their eventual employment prospects) and the strategies of law schools (which are focusing more intensely on U.S. News inputs to increase their rankings). For example, our earlier work showed that initial starting position in 1992 was a strong predictor of a gain or loss in a law school's median LSAT score over the next twelve years. ${ }^{64}$ Similarly, Sauder and Lancaster have documented a reflexivity dynamic in which each new rankings publication affects the relative size and credentials of each school's applicant pool the following year, thus giving rise to

61. AMERICAN BAR ASSOCIATION, 2007-2008STANDARDS FOR APPROVAL OFLAW SCHOOLS 39 (2007), available at http://www.abanet.org/legaled/standards/standards.html. "Basic information" includes "placement rates and bar passage data." Id. at 40 (Interpretation 509-1).

62. The U.S. News bar passage score is the school's first-time passage rate in the primary jurisdiction for graduates divided by the first-time bar passage rate in that jurisdiction.

63. See, e.g., STEPHEN P. Klein \& Roger Bolus, ANAlysis of July 2004 TEXas Bar EXam RESULTS BY GENDER AND RACIAL/ETHNIC GROUP (2004), http://www.ble.state.tx.us/one/analysis_0704tbe.htm (studying 2004 Texas bar exam results as part of a commissioned study and finding that "almost all of these differences [in bar passage rates among schools] can be explained by differences in the admissions scores of the students they graduate" and that "there is a nearly perfect relationship between a law school's mean total bar exam scale score and its mean LSAT score (the correlation is 0.98 out of a possible 1.00)").

64. Henderson \& Morriss, supra note 18, at 186-87 (summarizing data and regression results and noting that "[t]he relative gains and declines in median LSAT scores over time strongly support our initial starting position hypothesis"). 
potential upward and downward spirals. ${ }^{65}$ Further, Professor Stake's recent inspection of the differences between the 25th and 75th percentile LSAT scores documented a shrinking LSAT interquartile range ${ }^{66}$ of one quarter-point per year between 1998 and 2004. ${ }^{67}$

Not surprisingly, this process of credentials stratification has coincided with-and, we believe, partially caused-a reduction in the observed variability in bar passage scores (that is, lower ranked schools are generally receiving lower scores and higher ranked schools are generally receiving higher scores). Since 1997, when U.S. News first included bar passage as part of its placement methodology, the year-to-year correlations in school bar scores increased from $0.730(\mathrm{~N}=172)$ in $1997-1998$ to $0.870(\mathrm{~N}=177)$ in $2005-2006$. As shown in Figure 1, there is a strong upward trend line. However, it is important to emphasize that the inclusion of the bar passage score in the U.S. News rankings is not the causal factor for the upward sloping trend line between 1997-1998 and 2000-2001. Because any change in admission criteria designed to affect bar passage would not appear for four years, the only possible nexus with U.S. News is a general trend toward higher numerical credentials, which would offer the potential for immediate year-to-year rankings gains.

65. See Michael Sauder \& Ryon Lancaster, Do Rankings Matter? The Effects of the U.S. News \& World Report Rankings on the Law School Admissions Process, 40 LAW \& SoC'Y REv. 105, 123-24 (2006) (using multivariate regression analysis to show how slight upward or downward movement in U.S. News rankings affect the number and credentials of applicants to a law school the following year).

66. Interquartile range is the difference between the 75th and 25th percentile figures. See AlAN AGRESTI \& BARBARA FinLAY, STATISTICAL METHODS FOR THE SOCIAL SCIENCE 62-63 (3d ed. 1997).

67. Jeffrey E. Stake, Minority Admissions to Law School: More Trouble Ahead, and Two Solutions, 80 ST. JOHN's L. REV. 301, 312-13 (2006) ("When the difference between the P75 and $\mathrm{P25}$ at each school is regressed on time, the coefficient on the year is -.247 , which is significant at better than the .001 level. ... The average width of the midrange in 2004 was 5.4, down from 6.8 in 1998.") 
Figure 1. Year-to-Year Correlations of U.S. News Bar Passage Scores

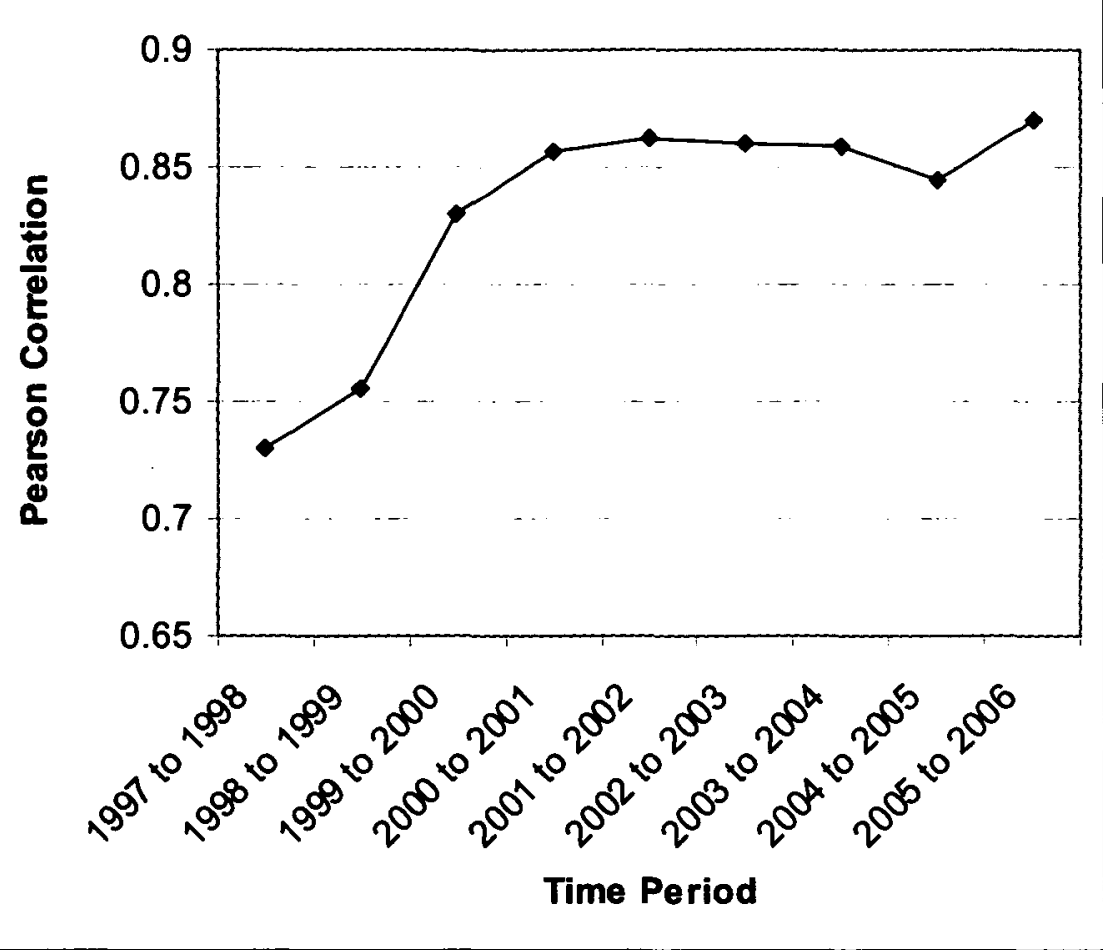

We think that the most likely explanation for the reduced variability in bar passage scores is the credentials stratification that occurred between 1993 and 1996. During this time period, the number of law school applicants plummeted from a high-water mark of 99,326 in the $1990-1991$ admission cycle to 76,687 in $1995-1996 .^{68}$ With fewer high-credentialed applicants, the average median LSAT score reported in U.S. News declined 1.31 points between 1993 (the first year for the 180-point LSAT scale) and 1996. Because of applicants' preferences for higher status schools, law schools at the top of the hierarchy had the ability to hold onto to their median LSAT. Lower ranked schools thus felt the overwhelming brunt of the declining applicant pool, as shown in Table 4.

68. See LAW SCH. AdMISSION COUNCIL, MinORITY DataBoOK 24 \& tbl.VI (2002) (summarizing applicant volume, ethnicity, average GPA, and LSAT from 1984-1985 to fall 2000). 
Table 4. Change in Median LSAT from 1993 to 1996, by 1992 Starting Position

\begin{tabular}{|l|c|c|c|c|c|}
\hline 1992 Rank & Median & Mean & S.E. Mean & Std. Dev. & Valid N \\
\hline \hline Top 16 & 0.00 & -0.06 & 0.382 & 1.526 & $\mathrm{~N}=16$ \\
\hline Rest of 1st Quartile & -1.00 & -0.82 & 0.186 & 0.983 & $\mathrm{~N}=28$ \\
\hline Second Quartile & -1.00 & -1.20 & 0.194 & 1.286 & $\mathrm{~N}=44$ \\
\hline Third Quartile & -2.00 & -2.00 & 0.228 & 1.510 & $\mathrm{~N}=44$ \\
\hline Fourth Quartile & -1.00 & -1.46 & 0.309 & 1.931 & $\mathrm{~N}=39$ \\
\hline
\end{tabular}

Since the LSAT has predictive power for bar passage, ${ }^{69}$ the credentials stratification of 1993 to 1996 would likely produce a similar effect on bar scores during the 19972000 time period when the students admitted between 1993 and 1996 were sitting for the exam. This explanation is consistent with the upward-sloping trendline in Figure 1.

An important additional source of variation, however, is the changes in jurisdiction minimum bar exam "cut scores" (the minimum scores needed to pass the bar exam). These scores were on the rise in many jurisdictions throughout the $1990 \mathrm{~s} .{ }^{70}$ Because the bar passage score is the ratio of a school's bar passage rate to the jurisdiction's overall rate, a high cut score in the measured jurisdiction (and thus lower overall bar passage) attenuates bar passage score, thus producing larger ranges for schools within the affected jurisdiction. ${ }^{71}$

Ohio, which has nine ABA-approved law schools, presents a vivid example of how the process operates. In July 1996, the Ohio Supreme Court authorized an increase in its minimum passing score to be phased in over the next two years. ${ }^{72}$ Prior to the new standard, the U.S. News bar passage input ratio for Ohio schools (relied upon for the rankings published in March 1997) ranged from 0.96 (Ohio Northern) to 1.08 (Capital), which is a spread of 0.12 points. At the time, Ohio's first-time bar passage rate was $93 \%$, which was relatively high compared to other states. Two years later, when the first-time bar passage rate dropped to $78 \%$, the bar passage ratio ranged from 0.76 (Ohio Northern) to 1.21 (University of Cincinnati), which resulted in a spread of 0.45 points. In subsequent years, the spread between highest and lowest bar passage rate has remained relatively large. ${ }^{73}$ Obviously, independent of any other changes in the U.S. News rankings methodology, the change in the cut score both positively and

69. See, e.g, Linda F. Wightman, LSAC National Longrtudinal Bar Passage Study 37-54 (1998) (presenting detailed empirical evidence showing that LSAT scores and law school grades are the two strongest predictors of bar passage); Richard H. Sander, A Systemic Analysis of Affirmative Action in American Law Schools, 57 STAN. L. REv. 367, 442-45 (2004) (same).

70. See Deborah J. Merritt, Lowell L. Hargens, \& Barbara F. Reskin, Raising the Bar: A Social Science Critique of Recent Increases to Passing Scores on the Bar Exam, 69 U. CIN. L. REv. 929, 929 \& n.1 (2001) (reporting that during the 1990s approximately a dozen states raised the minimum score required to pass the bar exam).

71. A few schools experienced a shift from one year to the next because their plurality bar jurisdiction changed (e.g., from Kentucky to Ohio), but this was relatively rare.

72. James Bradshaw, Law Dean Says Bar Exam Is Too Tough, Columbus DisPatch, Nov. 23, 1998, at 1A (noting that "[t]he Ohio Board of Bar Examiners raised the minimum passing score on the state bar exam in 1996 and 1997" in an effort to improve minimum competence).

73. The spreads were 0.31 in $2000 ; 0.38$ in $2001 ; 0.39$ in $2002 ; 0.25$ in $2003 ; 0.36$ in 2004; 0.40 in 2005; and 0.24 in 2006. 
negatively affected the relative bar passage scores of several Ohio law schools and, in general, echoed the effects of stronger or weaker entering credentials.

During the late 1990s, the combined pressures of U.S. News rankings and higher cut scores forced many law schools to formulate strategies to improve their school's bar passage performance. These strategies generally fell into one of three categories: (1) improving the characteristics linked to bar passage of their entering classes, (2) implementing programs to improve bar passage for their students, ${ }^{74}$ and (3) weeding out students unlikely to pass the bar exam before they graduate. ${ }^{75}$

LSAT scores are a predictor of bar passage, although a highly imperfect one. In particular, for the range of students in most entering law school classes, entering students with low LSAT scores are more at risk of failing the bar exam than are entering students with higher LSAT scores. ${ }^{76} \mathrm{~A}$ law school desiring to improve its bar passage rate later could either (a) reduce the overall class size by not admitting students with lower LSAT scores that it would have admitted previously (and so shrinking the class), or (b) admit the same number of students, but favor students with higher LSAT scores at the expense of holistic review. ${ }^{77}$ Given that many law schools already put heavy emphasis on LSAT and UGPA statistics in admissions, making an additional effort to improve their U.S. News rankings further reduces the scope for admitting students with interesting backgrounds but low scores.

Changing the curriculum and/or teaching methods to enhance bar passage is the second option. A few schools have made major efforts in this regard, but there is relatively little statistical evidence on the actual effects of such policies. ${ }^{78}$ Designing and implementing such a study would be relatively straightforward, as law schools have (or could easily obtain via surveys like the Law School Survey of Student Engagement ${ }^{79}$ ) much of the data needed to evaluate the courses and methods most likely to enhance bar passage.

74. See Committee on Bar Admissions and Lawyer Performance \& Richard White, AALS Survey of Law Schools on Programs and Courses Designed to Enhance Bar Examination Performance, 52 J. LEGAL Educ. 453, 456-57 (2002) [hereinafter AALS Survey] (reporting results of fall 1999 survey in which forty-two of 108 responding law schools (38.9\%) indicated that they provide or sponsor at least some "activities, programs, or courses specifically designed ... to enhance bar examination performance").

75. See Steven C. Bahls, Standard Setting: The Impact of Higher Standards on the Quality of Legal Education, THE BAR EXAMINER, Nov. 2001, at 15, 15 (noting that many law schools have dealt with bar passage problems by "increasing academic attrition").

76. See WighTMAN, supra note 69 , at $29,49 \&$ n. 84 .

77. See, e.g., Bahls, supra note 75, at 15 (Dean of Capital University Law School reporting that in an effort "to improve bar performance," Capital shrank the size of its entering class and admitted fewer students with lower LSAT and UGPA and noting the unfortunate side effect is that "many ... potentially strong future lawyers are being denied admission to law school" as a result).

78. An exception is University of Richmond School of Law, which implemented a rigorous academic support program that posted significant bar passage gains among participants whose law school GPA placed them in the bottom half of the class. See Linda Jellum \& Emmeline Paulette Reeves, Cool Data on a Hot Issue: Empirical Evidence that a Law School Bar Support Program Enhances Bar Performance, 5 NEv. L.J. 646, 671-80 (2005) (reporting four years of detailed results).

79. The Law School Survey of Student Engagement (LSSSE) is an annual survey of 
The third option is to winnow the entering class to remove students likely to fail the bar. ${ }^{80}$ Because first-year law school grades are the best predictor of bar passage, ${ }^{81}$ law schools could improve bar passage without changing admissions policies by using first-year law student (" $1 \mathrm{~L}$ ") grades as a means of selecting students to flunk out (by raising the required GPA to maintain good standing) or as a means to select students to encourage to depart. Compared to reducing class size, increasing attrition has the advantage of requiring a smaller revenue loss, which could be important for tuitiondependent schools.

Figure 2. Change in Attrition by Year of Law School, 1997-2004

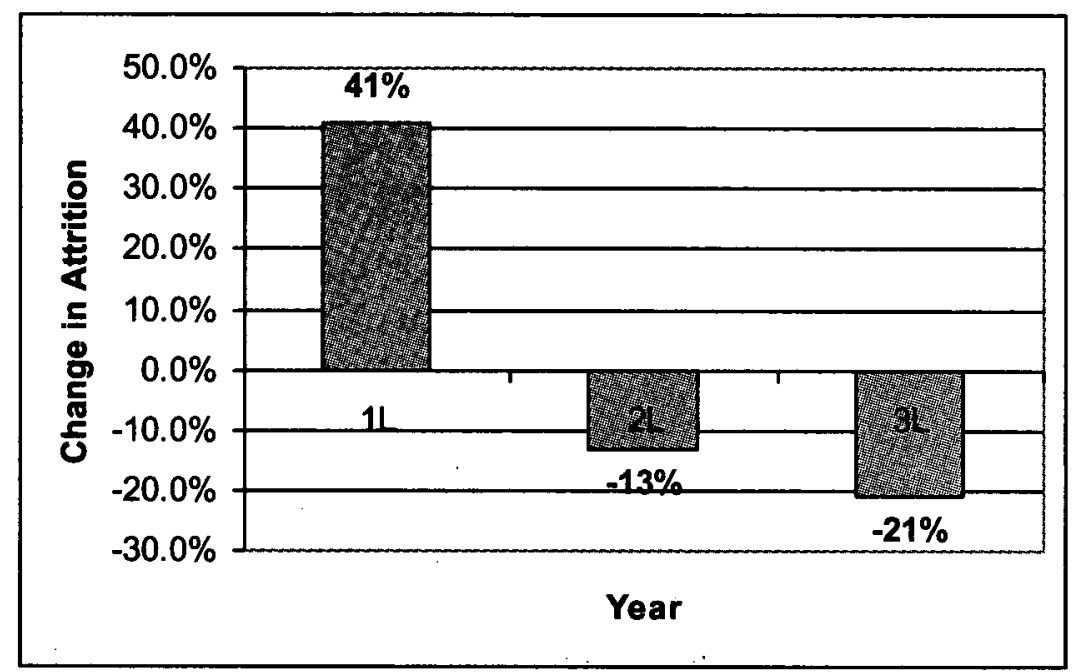

Inspection of the aggregate ABA data on law school attrition revealed clear evidence that $1 \mathrm{~L}$ attrition has sharply increased over the last several years. Between 1997 and 2004, law school attrition as a proportion of total enrollment increased $20.6 \%$. Yet, as shown in Figure 2, when these figures are disaggregated by law school year, the increase is entirely due to a massive increase in $1 \mathrm{~L}$ attrition, which shot up $41.0 \%$ while there were concomitant declines in the $2 \mathrm{~L}(-13.3 \%)$ and $3 \mathrm{~L}(-21.3 \%)$ years. $^{82}$

students at participating law schools. It is designed to gauge various aspects of the law school experience, including how students spend their time, how challenging their coursework is, their interaction with faculty, and their impressions of their own educational gains. Since 2003, over 100 law schools have participated in at least one LSSSE survey. See Law School Survey of Student Engagement, About LSSSE, http://www.lssse.iub.edu/html/about_lssse.cfm; Law School Survey of Student Engagement, http://ssse.iub.edu/html/quick_facts.cfm.

80. This trial-and-error method of attrition was originally championed by the famous Professor Wigmore. See John H. Wigmore, Juristic Psychopoyemetrology-Or, How to Find Out Whether a Boy Has the Makings of a Lawyer, 24 ILL. L. REv. 454, 463 (1929) (advocating first-year grades as the best method to determine whether a student had ability to become an able lawyer).

81. See supra note 69 and accompanying text.

82. Authors' calculations from attrition data posted on the ABA Web site. See Total J.D. Attrition, http://www.abanet.org/legaled/statistics/charts/stats\%20-\%2017.pdf. During the 1997 
To further examine this issue, we collected attrition data from the 1998 and 2005 editions of the ABA-LSAC Official Guide to ABA-Approved Law Schools. This information is summarized in Table 5. When the attrition data are analyzed by 1997 U.S. News rankings, the most striking feature is that schools in Tiers 2,3 , and 4 comprised the entire surge in $1 \mathrm{~L}$ attrition. In terms of change in academic $1 \mathrm{~L}$ attrition, it is highly unlikely that the 1.76 students per law school mean increase from 1997 to 2004 is due to random chance. Using a paired sample $t$-test that compared each school's reported $1 \mathrm{~L}$ academic attrition in 1997 to the 2005 figure, the increase was statistically significant at $p=0.015(t$-statistic $=-2.465)$.

Table 5. Change in IL Attrition, 1997-2004

\begin{tabular}{|c|c|c|c|c|c|c|c|}
\hline \multirow[b]{2}{*}{1997 Rank } & \multicolumn{2}{|c|}{$\begin{array}{c}\Delta \text { in } 1 L \text { Academic } \\
\text { Attrition }\end{array}$} & \multicolumn{2}{|c|}{$\begin{array}{c}\Delta \text { in Other 1L } \\
\text { Attrition }\end{array}$} & \multicolumn{2}{|c|}{$\begin{array}{c}\Delta \text { in Total 1L } \\
\text { Attrition }\end{array}$} & \multirow[b]{2}{*}{ Valid $\mathbf{N}$} \\
\hline & Mean & Median & Mean & Median & Mean & Median & \\
\hline Top 16 & -0.19 & 0.00 & -0.19 & -0.50 & -0.38 & -0.50 & $N=16$ \\
\hline Rest of Tier 1 & -0.28 & 0.00 & 0.06 & -1.00 & -0.22 & -1.50 & $\mathrm{~N}=36$ \\
\hline Tier 2 & 0.18 & 0.00 & 3.72 & 3.00 & 3.90 & 2.50 & $\mathrm{~N}=50$ \\
\hline Tier 3 & 3.10 & 2.00 & 2.45 & 3.00 & 5.55 & 4.00 & $\mathrm{~N}=29$ \\
\hline Tier 4 & 5.21 & 4.50 & 6.05 & 3.50 & 11.26 & 13.00 & $\mathrm{~N}=42$ \\
\hline All Schools & 1.76 & 0.00 & 2.95 & 1.00 & 4.71 & 2.00 & $\mathrm{~N}=173$ \\
\hline
\end{tabular}

Also potentially troubling are the trends for non-academic and total $1 \mathrm{~L}$ attrition. One possible explanation is increased transfers of students after their first year of law school, as many highly ranked schools open their door to $2 \mathrm{~L}$ students whose lower credentials have no effect on U.S. News rankings. ${ }^{83}$ An alternative and more troubling explanation is that at least some Tier 2 and below schools are underreporting academic attrition. Such a strategy would be attractive because high academic attrition hinders law school recruitment efforts, giving schools an incentive to characterize $1 \mathrm{~L}$ departures as non-academic even if poor graduation prospects may have motivated a voluntary decision to withdraw. ${ }^{84}$

\section{Assessing the Changes}

As noted in Parts II.A and II.B above, the first several years of U.S. News rankings were accompanied by constant tinkering with the placement components. As law students and legal employers began to rely upon the rankings, law schools paid much

to 2004 observation period, 4L attrition remained statistically unchanged.

83. We discussed this gaming strategy in our earlier work. Henderson \& Morriss, supra note 18, at 191. See also Leigh Jones, “No" Sometimes Means “Later", NAT'L L.J., Sept. 11, 2006, at S1, S11 (discussing the trend toward more 2L transfers to elite law schools); Whitman, supra note 58 (President of AALS reporting on the transfer students gaming strategy).

84. For example, many schools require a minimum GPA for graduation; students who perform below that level during the $1 \mathrm{~L}$ year have the option of continuing their studies on a probationary basis. The decision to withdraw from law school is therefore deemed voluntary. Anecdotally, we know of several schools that have increased the minimum GPA required for good standing or instituted academic waming programs for students with marginal GPAs. 
closer attention to their reporting and adopted strategies to heighten their relative success. To protect the integrity of its rankings (or, perhaps more accurately, to preserve and grow its rankings franchise), U.S. News adopted practices that penalized law schools for submitting incomplete data. ${ }^{85}$ When it became obvious that law schools were inflating or mischaracterizing several of their reported numbers (particularly starting salary figures), the ABA mandated the collection and publication of basic employment (that is, employed or unemployed) and bar passage data. ${ }^{86}$

The methodology that eventually emerged from this process was a compromise system driven by a desire by the magazine to utilize only verifiable information that was also submitted to the ABA. Despite the fact that many (if not most) aspiring lawyers would value school-level information on employer interview activity and starting salaries of recent graduates, these data are no longer part of the U.S. News ranking methodology.

Unfortunately, contrary to the perceptions of the U.S. News editors in 1997, reliance on information submitted to the ABA has not solved the problem of inflated data. By the same token, the U.S. News rankings have become so entrenched within the legal education environment that the survival of the rankings no longer depends upon valid and accurate inputs. As a result, what has emerged among U.S. News, the law schools, and the ABA is a ranking system that under-serves prospective students by failing to facilitate meaningful competition on what matters a great deal to students: postgraduation outcomes.

Several academic commentators have correctly noted that combining several numerical inputs into a single index of quality has the potential to set in motion in a reflexivity dynamic that effectively orders the behavior and perceptions of all market participants: law students, ${ }^{87}$ legal academics, ${ }^{88}$ law schools, ${ }^{89}$ law review editors, ${ }^{90}$ and legal employers. ${ }^{91}$ U.S. News is often blamed for this outcome. Yet, the source of

85. See supra notes $37-51$ and accompanying text.

86. See supra notes $47-49$ and accompanying text.

87. See Sauder \& Lancaster, supra note 65 , at 122-24 (reporting how minute changes in rankings affect the numerical quality of applicant pools).

88. See Jeffrey E. Stake, The Interplay Between Rankings, Reputations, and Resource Allocation: Ways Rankings Mislead, 81 IND. L.J. 229, 250-55 (2006) (presenting statistical evidence that the prior year's U.S. News ranking affects the direction of the following year's academic reputation input).

89. See Wendy Nelson Espeland \& Michael Sauder, Quantitative Authority and the Reflexivity of Rankings, Paper Presented at the Law \& Soc'y Conference, Chi., Ill. (2004) (documenting through media reports and interviews with faculty and administrators how law schools have changed policies and allocated resources to improve their U.S. News standing).

90. See Stake, supra note 88, at 266 ("Because some student law review editors consider the author's institution's rank in U.S. News, it is in a prospective employee's best interest to pay some attention to the rankings when choosing employers."); Dan Subotnik \& Glen Lazar, Deconstructing the Rejection Letter: A Look at Elitism in Article Selection, 49 J. LEGAL EDUC. 601, 605-07 (1999) (discussing the belief of many law professors that "editors' selections of articles are [at least partially] based on extraneous factors such as the rank of the author's school");

91. See Henderson \& Morriss, supra note 18, at 182 \& n.64 (noting "market evidence that law firms rely upon the U.S. News rankings to direct their recruiting efforts" and citing to book prepared by a leading law firm recruiter that uses the Top 50 schools as ranked by U.S. News as 
much of the criticism emanating from law schools may be the loss of cartel-like control $^{92}$ over market information and, as a consequence, having to cope with the vicissitudes of increased competition-albeit, still quite incomplete-within a multibillion dollar legal education industry. ${ }^{93}$ Although we agree with the critics who argue that various law school attributes, including post-graduation success, cannot be reliably reduced to a single quality index ${ }^{94}$ - which is, after all, the hallmark of the U.S. News franchise-we think the magazine has, on balance, enhanced the welfare of students by forcing a modicum of comparable information into the public domain.

Even as law schools regularly complain about U.S. News as the "800-pound gorilla of legal education," 95 they hold the power to relegate the magazine to a marginal position by embracing full disclosure of the data they control. In particular, if schools provided a standardized range of trustworthy information on the type of job opportunities represented by on-campus interviews, the type of employment graduates obtained, the career paths of graduates, placement within specific geographic regions, and the types of programs career services offices provided, students would be better positioned to evaluate law school programs. Another important index for many students would be bar passage information that is reported by entering credentials. These statistics would provide concrete evidence that a particular law school, vis-à-vis its competitors, provides a better (or worse) probability of passing the bar. When a prospective student is evaluating an investment of three years and $\$ 100,000$ or more (often largely in the form of loans), this information is likely to be more salient than whether a law school is in Tier 2,3 or 4 .

\section{ANALYSIS OF POST-GRADUATION MEASURES}

U.S. News rankings are now the scorecard of legal education, and law schools compete by improving the numbers they report on the various inputs. ${ }^{96}$ Our earlier

its cutoff).

92. On the cartel-like nature of legal education, see Harry First, Competition in the Legal Education Industry (I), 53 N.Y.U. L. Rev. 311 (1978); Harry First, Competition in the Legal Education Industry (II): An Antitrust Analysis, 54 N.Y.U. L. REv. 1049 (1979); George B. Shepherd, No African-American Lawyers Allowed: The Inefficient Racism of the ABA's Accreditation of Law Schools, 53 J. LEGAL EDUC. 103 (2003).

93. There is strong historical evidence that law schools have actively opposed the compilation of information that would facilitate direct school-to-school comparisons. Compare Charles D. Kelso, Adding up the Law Schools: A Tabulation and Rating of Their Resources, LEARNING AND THE LAW, Summer 1975, at 38 (ranking the faculty and library resources of all ABA-approved law schools), with Charles D. Kelso, In Defense of the Mathematics of Law School Evaluation: An Answer to Our Critics, LEARNING AND THE LAW, Fall 1975, at 14 (responding to vociferous criticism on the ratings from law school administrators), and Adding up Law Schools is a Poor Way to Count: The Critics of Our Resources Index Do Their Own Arithmetic, LEARNING AND THE LAW, Fall 1975, at 16 (publishing letters from several law school deans, all of which express the opinion that the author's law school was undervalued).

94. See, e.g., Leiter, supra note 12, at 51 (arguing that "there is no way [various inputs of law school quality] can be meaningfully amalgamated" into a single ranking system).

95. Jones, supra note 57 (quoting a common characterization of U.S. News rankings).

96. See Wellen, supra note 58 (documenting how elite law schools focus on issues of costaccounting for university-provided facilities or the commercial value of electronic databases as a way to boost average expenditures per student). 
work on rankings used multivariate regression analysis to pinpoint factors that influenced changes in a school's median LSAT score over time. ${ }^{97}$ Based on that research and the other literature on rankings, we think that some rankings-related competition improves legal education (for example, increasing law schools' concern whether their students pass the bar exam), some has no impact (for example, shifting faculty leaves from fall to spring semester to boost faculty counts for purposes of calculating student-faculty ratios), and some is detrimental (for example, increasing the emphasis on LSAT and UGPA in admissions).

As law school constituencies increasingly treat their schools' U.S. News rankings as an important indicator of success, and the obvious "low-hanging fruits" (such as answering U.S. News questionnaires rather than allowing the magazine to impute values) have been harvested, law school deans and faculties are casting about for new strategies. One of the most interesting is the Moneyball strategy inspired by the Oakland Athletics' success in baseball. ${ }^{98}$

Briefly, a Moneyball strategy focuses on data-driven improvements in strategy in areas from faculty hiring to student admissions. We think that by embracing data transparency and competition, law schools will have the tools and incentives to play Moneyball with respect to their post-graduation success and that this will benefit their students. In this Part, we provide an empirical analysis of post-graduation U.S. News input variables which supports that conclusion. Part III.A uses multivariable regression analysis to identify factors that influence the "employed at graduation" and "employed at nine months" inputs. Part III.B relies upon descriptive statistics to highlight some of the idiosyncrasies of the U.S. News bar-passage statistics.

\section{A. Determinants of Employment Variables}

As discussed in Part I, post-graduation employment data account for $18 \%$ of the total weighting in U.S. News rankings methodology; bar passage accounts for the remaining $2 \%$ (see Table 1 ). This is currently subdivided into $4 \%$ for employment at graduation and $14 \%$ for employment at nine months. ${ }^{99}$ Obviously, from the perspective of law schools, these are important variables.

97. See Henderson \& Morriss, supra note 18, at 182-92. Specifically, we reported empirical evidence that (1) the market for students is segmented into regional and national markets that operate under different rules; (2) a school's relative starting position matters; (3) within the regional market, students discount rank for geographic proximity to vibrant legal employment markets; (4) within the regional market, students discount rank for lower tuition and law school debt; and (5) there is little or no association between higher reputation scores and gains in the median LSAT; (6) various gaming strategies are associated with higher LSAT scores. See id.

98. Michael Lewis, Moneyball: The ART OF Winning An Unfair Game (2003). See Paul L. Caron \& Rafael Gely, What Law Schools Can Learn from Billy Beane and the Oakland Athletics, 82 TEx. L. REv. 1483 (2004) (book review) (giving a cogent explication of why this book on baseball has important implication for the legal academy); Henderson \& Morriss, supra note 18, at 197-202 (drawing upon the Moneyball philosophy to formulate three data-driven strategies to increase a law school's median LSAT); MoneyLaw, http://www.moneylaw.blogspot.com (popular law professor blog devoted to the application of Moneyball principles to the legal academy).

99. See Table 1, supra, p. 7. 
As we began the process of analyzing the U.S. News employment data, we observed three striking patterns, illustrated in Table 6 below. First, the results are remarkably uniform throughout the law school hierarchy. The Top 16 law schools consistently posted employment at graduation rates of $90.0 \%$ to $99.8 \%$ (and $97.6 \%$ to $100 \%$ for employed at nine months), with the percent employed falling through the remainder of the hierarchy. Second, there is much less variation among schools in the employed at nine months data. The roughly 28 point spread in employment at graduation numbers between Tier 4 and the remainder of Tier 1 (i.e., non-Top 16) is cut in half within nine months of graduation. Third, many law schools simply refuse to disclose certain information to the U.S. News. Nearly fifty law schools ranked in the 2006 edition failed to report figures for number of students employed at graduation $(\mathrm{N}=133)$, and almost all of them were ranked in Tiers 2,3 , or 4 . Yet, virtually every law school supplied U.S. News with employed at nine months data $(\mathrm{N}=181)$; we suspect that they did so because the numbers were sufficiently encouraging that they could be shared with prospective students while the employed at graduation numbers were not. ${ }^{100}$

Table 6. U.S. News Employment Data by Tier, 2006

\begin{tabular}{|c|c|c|c|c|c|c|}
\hline Rank & Mean & 25th Percentile & Median & 75th Percentile & S.E. Mean & Valid $\mathbf{N}$ \\
\hline \multicolumn{7}{|c|}{ Employed at Graduation } \\
\hline Top 16 & $96.5 \%$ & $95.0 \%$ & $97.0 \%$ & $98.6 \%$ & $0.6 \%$ & $N=16$ \\
\hline Rest of Tier 1 & $79.8 \%$ & $72.2 \%$ & $80.7 \%$ & $87.6 \%$ & $1.7 \%$ & $N=33$ \\
\hline Tier 2 & $71.4 \%$ & $65.6 \%$ & $71.4 \%$ & $77.0 \%$ & $1.4 \%$ & $\mathrm{~N}=44$ \\
\hline Tier 3 & $64.5 \%$ & $52.9 \%$ & $63.5 \%$ & $77.8 \%$ & $2.6 \%$ & $\mathrm{~N}=19$ \\
\hline Tier 4 & $51.6 \%$ & $44.3 \%$ & $53.7 \%$ & $56.6 \%$ & $2.9 \%$ & $\mathrm{~N}=21$ \\
\hline All Schools & $\mathbf{7 2 . 4 \%}$ & $60.2 \%$ & $72.5 \%$ & $85.1 \%$ & $1.4 \%$ & $\mathrm{~N}=\mathbf{1 3 3}$ \\
\hline \multicolumn{7}{|c|}{ Employed at Nine Months } \\
\hline Top 16 & $99.1 \%$ & $98.9 \%$ & $99.2 \%$ & $99.5 \%$ & $0.2 \%$ & $\mathrm{~N}=16$ \\
\hline Rest of Tier 1 & $96.4 \%$ & $95.4 \%$ & $97.2 \%$ & $98.7 \%$ & $0.5 \%$ & $\mathrm{~N}=34$ \\
\hline Tier 2 & $94.3 \%$ & $92.5 \%$ & $94.4 \%$ & $96.9 \%$ & $0.4 \%$ & $\mathrm{~N}=50$ \\
\hline Tier 3 & $91.1 \%$ & $88.5 \%$ & $91.1 \%$ & $94.2 \%$ & $0.7 \%$ & $\mathrm{~N}=36$ \\
\hline Tier 4 & $82.3 \%$ & $78.2 \%$ & $83.9 \%$ & $87.3 \%$ & $1.1 \%$ & $\mathrm{~N}=45$ \\
\hline All Schools & $91.5 \%$ & $88.3 \%$ & $92.9 \%$ & $97.2 \%$ & $0.6 \%$ & $\mathrm{~N}=181$ \\
\hline
\end{tabular}

100. We have already discussed reasons why the law school employment numbers should be viewed with skepticism. See supra Part II.B.1. The puffery, however, appears to be relatively uniform and systemic. While we may not give much credence to the actual numbers that individual law schools report, the techniques used to boost these employment variables have become established lore among most competent law school administrators. As a result, despite a compression of the underlying scale, the ordinal ranking of employment outcomes among law schools may remain largely intact. In other words, if all law schools game their employment numbers in similar fashion, it may still be possible to tease out meaningful factors that affect employment outcomes. 


\section{Employed at Graduation}

To explore the determinants of the employment at graduation variable, we specified a linear regression model with the 2006 U.S. News's "percent employed at graduation" as the dependent variable. (The employment statistics reflect a two-year lag. Thus, the 2006 employment inputs reflect outcomes for the class of 2004.) Because our earlier work suggested that elite law schools tend to operate in a different market that follows different rules, ${ }^{101}$ we limited our analysis to schools outside the Top 16.

Our independent variables included six factors that could potentially influence employment outcomes:

(1) The school's 200425 th percentile LSAT score. This serves as a measure of law schools' overall rank. We hypothesized that law school rank influenced potential employers' hiring decisions because employers may be willing to take more of a chance on candidates with average or below-average grades if they come from a more prestigious institution. ${ }^{102}$ We used the 25 th percentile score, rather than the 75 th percentile score, because we hypothesized that students at the bottom of the class were more likely to have trouble securing immediate employment than students at the top of the class.

(2) The natural log of the number of on-campus interviews by NALP employers. ${ }^{103}$ We included this variable based on the simple hypothesis that more $\mathrm{OCI}$ interviews reflect greater employer interest in a law school's graduates. We used the natural log because the marginal benefit of additional interviews declines as the total number of employers approaches or exceeds the number of students who are seeking jobs. ${ }^{104}$

(3) The percentage of part-time students. Our hypothesis was that part-time students had more control over when they graduated than did full-time students, because parttime students can vary the number of hours they take per semester to speed or slow graduation. Once a student has secured permanent employment, our hypothesis was that they would attempt to complete their education as quickly as possible, making them more likely to be employed at graduation. Alternatively, a student could be continuing on with their current employer after graduation or could have secured permanent employment while in school and be finishing law school part-time while working.

(4) A dummy variable, coded 1 for historically black institutions and 0 otherwise. ${ }^{105}$ We hypothesized that legal employers' interests in improving their firms' racial

101. See Henderson \& Morriss, supra note 18 , at $182-86$.

102. See William C. Kidder, Portia Denied: Unmasking Gender Bias on the LSAT and Its Relationship to Racial Diversity in Legal Education, 12 YALE J.L. \& FEMINISM 1, 22-24 \& nn.103-104 (collecting sources that document how some legal employers, including law firms and federal judges, have relied on the LSAT in making hiring decisions).

103. These data were compiled by National Jurist magazine. See Colleen Gareau, Who's Hiring on Campus This Fall?, NaT'L JURIST, Sept. 2005, at 16, 20 tbl..

104. For example, 248 OCI employers visited Notre Dame Law School, which has a typical class size of 185 students. The marginal benefit of the 248th employer visit was presumably considerably less than the marginal benefit of the 100th employer visit.

105. To assess whether law schools with higher percentages of minority students generally garner higher "employment at graduation" numbers, we tried an alternative specification that included percentage of minority students as an independent variable. However, this variable was 
diversity would lead to increased hiring at schools that offered firms the greatest opportunities to reach minority students. ${ }^{106}$

(5) A dummy variable, coded 1 if a law school was located in a Top 10 corporate law firm city and 0 otherwise. We hypothesized that this would increase the volume of law students seeking to enter the market ${ }^{107}$ from a wide variety of law schools (including schools outside the city), and so reduce the chances of employment at graduation.

(6) The 2004 U.S. News lawyer/judge reputational variable. Although this number is routinely dismissed as representing mostly noise in discussions of law school rankings, ${ }^{108}$ we hypothesized that it could capture employer perceptions of a law school within a particular regional market. Schools with higher lawyer/judge reputation scores would thus do better in placing graduates more quickly.

As summarized in Table 7, this specification produced a model with fairly strong predictive power, explaining approximately $45 \%$ of the overall variance in employment at graduation among non-elite law schools. The results are largely consistent with our hypotheses and make intuitive sense. Higher 25th percentile LSAT scores, more interviews, a higher percentage of part-time students, and a concentration

not a significant predictor of employment.

106. See Leigh Jones, Law Firms Digging Deeper On Campus, NAT'L L.J., Nov. 27, 2006, at 1,10 (reporting that "amid calls from corporate clients to add minority attorneys or risk losing the clients' business, most big law firms have boosted their efforts to diversify" and citing example of Philadelphia-based firm Duane Morris, which "target[s] four or five schools with strong minority enrollments").

107. Using the number of Am Law 200 lawyers in the metropolitan statistical area (MSA) as the metric, the Top 10 corporate law markets are New York City $(21,210$ Am Law 200 lawyers); Washington, DC (13,512); Chicago (6988); Los Angeles (6475); San Francisco (5688); Boston (3904); Philadelphia (3155); Atlanta (2856); Houston (2753); Dallas (2742). As of 2003, these ten MSAs included 69.8\% of all Am Law 200 lawyers. See William D. Henderson, An Empirical Study of Single-Tier Versus Two-Tier Law Partnerships in the Am Law 200, 84 N.C. L. REv. 1691, 1720 tbl.2 (2006) (summarizing size of Top 10 corporate law markets).

As shown in the table below, the appeal of these markets is reflected in the compression of the LSAT interquartile range (the difference between the 25 th and 75 th percentiles) for law schools located inside and outside these major markets:

LSAT Interquartile Ranges in Law Schools, by Tier and Location

\begin{tabular}{llllll} 
U.S. News Rank & Market & Mean & S.E. Mean & Std. Dev. & Valid N \\
\hline \multirow{2}{*}{ Tier 1 } & Top 10 & 4.82 & 0.37 & 1.74 & $\mathrm{~N}=22$ \\
& Non-Top 10 & 4.93 & 0.21 & 1.09 & $\mathrm{~N}=28$ \\
Tier 2 & Top 10 & 4.00 & 0.26 & 1.08 & $\mathrm{~N}=18$ \\
& Non-Top 10 & 5.28 & 0.25 & 1.44 & $\mathrm{~N}=32$ \\
Tier 3 & Top 10 & 4.38 & 0.42 & 1.19 & $\mathrm{~N}=8$ \\
& Non-Top 10 & 5.04 & 0.25 & 1.35 & $\mathrm{~N}=28$ \\
Tier 4 & Top 10 & 4.40 & 0.29 & 1.12 & $\mathrm{~N}=15$ \\
& Non-Top 10 & 5.55 & 0.27 & 1.45 & $\mathrm{~N}=29$
\end{tabular}

108. See, e.g., Brian Leiter, More on the U.S. News Rankings Echo Chamber, Leiter Reports: A Philosophy Blog, Apr. 1, 2005, http://eiterreports.typepad.com/blog/2005/04/more_on_the_us_.html (noting that "[t]he lawyer/judge reputation rank fluctuates meaninglessly year in and year out"). 
of minority students all increased the employed at graduation percentage and presence in a Top 10 legal employer MSA decreased it.

Table 7. OLS Regression Results for Employed at Graduation, Class of 2004

\begin{tabular}{|l|c|c|c|c|}
\hline \multicolumn{1}{|c|}{ Variable } & B & S.E. & Beta & $p$-value \\
\hline (Constant) & -96.55 & 57.54 & - & 0.10 \\
\hline USN LSAT 25th Percentile & 0.91 & 0.41 & $0.293^{*}$ & 0.03 \\
\hline NALP OCI (LN) & $4.49 * *$ & 1.44 & $0.403^{* *}$ & 0.00 \\
\hline \% Part-Time & $20.18^{*}$ & 8.2 & $0.210^{*}$ & 0.02 \\
\hline Historically Black & $20.35^{*}$ & 9.39 & $0.190^{*}$ & 0.03 \\
\hline Top 10 MSA & $-5.59^{*}$ & 2.46 & $-0.190^{*}$ & 0.03 \\
\hline USN Lawyer/Judge Rep & 2.54 & 3.67 & 0.102 & 0.49 \\
\hline N =116 (excludes Top16) & Adj. $\mathrm{R}^{2}=0.446$ & \\
\hline
\end{tabular}

These results suggest several steps schools can take to improve their employed at graduation numbers. Most obviously, schools can recruit more students with (relatively) high LSAT scores to raise their 25 th percentile score. Although we say this is obvious, it is not a cheap strategy, as successfully recruiting such students likely requires extending non-need based scholarship aid to more students and other expensive measures. Similarly, a law school can improve its employed at graduation statistic by attracting more employers to interview at its campus. This could take the form of the relatively obvious step of more aggressive marketing to prospective employers.

Yet, it is possible that employed at graduation numbers could be enhanced by more radical steps, such as substantive changes to the curriculum that will enhance the skill set of students and make them more attractive to potential employers. As we have noted elsewhere, employers appear to operate on the model of "good quality in, good quality out." 109 We think it is plausible that a law school could gain a competitive advantage by enhancing the human capital of its students. Schools could also offer employers more transparent and reliable data on student performance than class rank and GPAs provide. Surely educational institutions can do more than identify and sort legal talent based on entering credentials. ${ }^{110}$ Pursuing such a strategy would require considerable resources and might be unpalatable to many law faculty members. Its benefits, however, may go beyond rankings and directly improve the level of preparation-and ultimate welfare-of our students.

Three of the four remaining independent variables also yielded statistically significant results. A higher percentage of part-time students boosted employed at graduation numbers, as did status as a historically black law school. In contrast, location in a Top 10 MSA was a drag on employment at graduation, presumably because graduates from local law schools are in competition with new graduates from a wide range of law schools outside the area for jobs in these desirable markets. Finally,

109. Henderson \& Morriss, supra note 18, at 199.

110. See id. at $199 \mathrm{n} .115$ (citing Baylor Law School as an example of a law school that appears to have fared well in the rankings by emphasizing faculty teaching rather than 
the U.S. News lawyer/judge reputation score had no statistically significant relationship to employment at graduation.

\section{Employed at Nine Months}

We now turn to the employed at nine months input variable, which is worth $70 \%$ of the total placement methodology. Our analysis was slightly complicated by the fact that $50 \%$ of the schools were narrowly clustered between $92.9 \%$ and $100 \%$ (a 7.1 point spread) while the other half stretched from $58.1 \%$ to $92.9 \%$. (a 34.8 point spread). In order to obtain a normal distribution for the dependent variable, we used a logarithmic transformation of the employed at nine months data. ${ }^{111}$

Using this transformed measure of employed at nine months as our dependent variable, we specified an OLS regression with the same six independent variables relied upon in the previous Part, which we hypothesized would have similar effects on the employed at nine months numbers. The results for this model are summarized in Table 8.

Table 8. OLS Regression Results of Graduated at Nine Months (transformed), Class of 2004

\begin{tabular}{|l|c|c|c|c|}
\hline \multicolumn{1}{|c|}{ Variable } & B & S.E. & Beta & p-value \\
\hline \hline (Constant) & -2.528 & 1.118 & -- & 0.025 \\
\hline USN LSAT 25th Percentile & $0.020^{*}$ & 0.008 & $0.300^{*}$ & 0.013 \\
\hline NALP OCI (LN) & $0.053^{*}$ & 0.025 & $0.216^{*}$ & 0.038 \\
\hline \% Part-Time & 0.074 & 0.150 & 0.034 & 0.623 \\
\hline Historically Black & -0.101 & 0.148 & -0.049 & 0.496 \\
\hline Top 10 MSA & -0.032 & 0.048 & -0.047 & 0.497 \\
\hline USN Lawyer/Judge Rep & $0.137^{*}$ & 0.068 & $0.243^{*}$ & 0.048 \\
\hline N = 162 (excludes Top 16) & Adj. $R^{2}=0.451$ & \\
\hline
\end{tabular}

The adjusted $\mathbf{R}$-squared statistics for the employed at graduation (0.446) and employed at nine months models $(0.451)$ indicate that both have similar predictive power. ${ }^{112}$ Nine months after graduation, the number of on-campus interviews and the 25th percentile LSAT score (i.e., a proxy for rank and depth of student quality) remain important predictors of post-law-school employment. However, the percentage of parttime students, presence in a Top 10 corporate law market, and being a historically black law school are no longer associated with higher employment levels.

scholarship).

111. The formulation for transformation was $\log _{10}(K$ - old variable), where $K$ equals the largest possible value plus one. BARBARA G. TABACHNICK \& LINDA S. FIDELL, UsING MULTIVARIATE STATISTICS 85 (3d ed. 1996) (suggesting transformation to correct for substantial negative skew). In turn, by subtracting the new variable from 2.00 , we preserved both the scale and direction of the underlying relationships-that is, higher employment at nine months would correspond to a larger, rather than a smaller, transformed variable. We also visually checked scatter plots of the dependent and independent variables to confirm the presence or absence of linear and non-linear relationships.

112. Compare Table 7 (reporting results of employed at graduation model), with Table 8 (reporting results of employed at nine months model). 
We think this difference in significant predictors reflects how the market absorbs legal talent. For example, the benefit of being a historically black law school may be limited to pre-graduation job recruitment because these schools attract more on-campus recruiters than do schools with comparable characteristics but which lack large pools of minority students. ${ }^{113}$ If the benefit is linked to pre-graduation access to employers, the benefit would not persist after graduation. Similarly, the employment statistics benefit of larger percentages of part-time students will also diminish after graduation. Likewise, if the influx of résumés from outside schools into Top 10 legal markets initially disadvantages students from local law schools prior to graduation, over time, the local markets can absorb those initially disadvantaged local graduates, particularly those who clear the hurdle of the bar exam.

From the perspective of law school deans attempting to boost their rankings, the most surprising finding is that the U.S. News lawyer/judge reputation score is associated with higher employment nine months after graduation. ${ }^{114}$ Despite evidence that the U.S. News academic reputation score is largely immune to change ${ }^{115}$ and may be simply an echo of the prior year's ranking, ${ }^{116}$ many law schools devote considerable resources to disseminating glossy brochures to other law schools in an effort to boost their scholarly profiles. ${ }^{117}$ More and better scholarship, and proper marketing to other academics, has become a fairly standard strategy for a law school trying to move up in the rankings. Compared to many other factors in the rankings process, we know relatively little about the U.S. News lawyer/judge reputation score. ${ }^{118}$ We do know that

113. Our regression analysis corroborates that historically black law schools, even after controlling for rank, law school size, and the number of large law firms with offices in the local market, tend to garner more on-campus interviews than other law schools. It is also possible that recruiting at historically black law schools allows firms to send a signal about the intensity of their commitment to diversity. The fact that a firm interviews at a historically black school can be publicized more readily than the number of minority candidates interviewed at other schools.

114. Note that we also ran a specification that included schools' U.S. News academic reputation scores. Despite being highly correlated with the lawyer/judge score, the academic variable had no predictive power for the "employed at nine months" variable. In contrast, the lawyer/judge variable was positively correlated with the "employed at nine month" variable and had a relatively low $p$-value of 0.068 .

115. See William D. Henderson, Variations in U.S. News Reputation over Time, Conglomerate Blog: Bus., Law, Econ., \& Soc'y, April 4, 2006, http://www.theconglomerate.org/2006/04/variation_in_us.html.

116. See Stake, supra note 88, at 250-55 (2006) (presenting statistical evidence that the prior year's U.S. News ranking affects the direction of the following year's academic reputation input).

117. See, e.g., Jay M. Feinman, The Five-Dollar Solution, 7 GreEn BAG 225, 225-26 (2004) (suggesting that law school deans preempt the staggering waste and expense of promotional material by sending their colleagues a letter summarizing some key highlights plus a five dollar bill the school would have spent on a fancy publication, eliminating the deadweight loss); Todd Zywicki, Dropping the U.S. News Fig Leaf, 9 GREEN BAG 8, 8 (2005) (decrying the wasteful annual ritual of disseminating "full-color, and glossy, and professionally photographed" news reports to law professors and administrators in the hope of influencing U.S. News reputational surveys). Of course, much of this material does not arrive on time for the balloting or is not targeted to the audience of potential voters, suggesting that law schools might profit from talking with the marketing department of their university's business school.

118. See Stephen P. Klein \& Laura Hamilton, Am. Ass'n of Law SchS., The Validity of 
the year-to-year correlation is lower than for the academic reputation. ${ }^{119}$ If a law school could influence this factor, it might get more rankings traction by investing resources in affecting bar opinion than from the largely futile efforts to alter academic reputation.

As we noted above, one potential strategy would be to emphasize activities valued by the practicing bar. Such a strategy might include encouraging faculty to pursue participation and leadership in national and local bar associations, providing high quality CLE programming, hiring faculty who publish scholarship and treatises that will be cited by lawyers and judges, ${ }^{120}$ and providing graduates with skills that are in demand by prospective employers. Not only would improving a school's lawyer/judge rating improve its rankings directly, but our regression results suggest that any subsequent boost among lawyers and judges will give graduates a slight competitive edge in their pursuit of post-graduation employment. Together with some intriguing anecdotal evidence about efforts at a few law schools to improve their graduates' skills (Baylor, for example), we think these results suggest a need for further research into both the U.S. News lawyer/judge reputation score and the impact of law schools' efforts at bolstering their graduates' skills on employment outcomes.

\section{B. Bar Passage}

In 1997, U.S. News's placement methodology began to include a measure of bar exam success in the rankings. This score is calculated by dividing the percentage of the school's first-time bar exam takers from the state where the largest number of graduates took the bar exam (which we'll term "the plurality state"), by the plurality state's overall first-time passage rate. The resulting ratio (scaled like all the rankings' components) counts for $10 \%$ of the placement score and $2 \%$ of the overall U.S. News rankings.

Success on the bar exam is certainly an important criterion by which prospective students and employers can judge law schools. U.S. News's introduction of bar passage data in 1997 was therefore a positive step. Unfortunately, there are several reasons why the bar passage rates from state to state are not commensurable. As a result, direct comparisons and rankings are destined to produce a misleading picture of law school quality. The problem of comparability stems from at least two sources: (1) systematic differences among states in the credentials of applicants sitting for their bar exams, and (2) differences among primary jurisdictions in both the content of exams and the cut scores used for common elements like the Multistate Bar Exam (MBE).

We offer three examples that show how these factors interact with each other to create intractable problems of commensurability. First, in the 2006 edition of the U.S. News rankings, the bar passage score for the sixth-ranked University of Chicago was

THE U.S. NEWS AND WORLD REPORT RANKING OF ABA LAW SCHOOLS (1998), http://www.aals.org/reports/validity.html\#review (noting that little is known about the survey of judges and lawyers).

119. Authors' calculations.

120. Cf. Harry T. Edwards, The Growing Disjunction Between Legal Education and the Legal Profession, 91 MrCH. L. REV. 34 (1992) (arguing that the work of elite legal educators is becoming increasingly irrelevant to practicing lawyers); Harry T. Edwards, The Growing Disjunction Between Legal Education and the Legal Profession: A Postscript, 91 MicH. L. REV. 2191 (1993) (reiterating and further developing this critique). 
1.16, while fourth-ranked New York University's bar passage score was 1.29. This difference stemmed largely from the lower overall pass rate on the New York bar exam (the plurality exam for NYU) compared to the Illinois bar exam (the plurality exam for Chicago), $75 \%$ vs. $85 \%,{ }^{121}$ rather than the schools' pass rates $(97.1 \%$ for NYU vs. 98.7\% for Chicago). It strikes us as implausible that Chicago students would do significantly worse than the NYU students on the New York bar exam (or better than Chicago students on the Illinois bar) given (a) the two schools' nearly identical entering credentials and faculty quality, and (b) that both institutions are "national" law schools that do not emphasize local law coverage in their programs. ${ }^{122}$ Indeed, it seems likely to us that, given the two schools' similar scores on most credentials and Chicago's slight edge on several large contributors to the overall score, that the difference in plurality bar exams contributes much of NYU's higher overall point total and higher rank. The U.S. News method of comparing bar exam results is thus producing variations in the results that are completely unrelated to differences in school quality.

A second confounding factor is significant biases in (a) the percentage of a school's students taking the plurality bar exam, and (b) which students-relatively stronger or weaker - take the plurality exam. For example, because over $20 \%$ of all Am Law 200 lawyers are employed in the New York City MSA, ${ }^{123}$ one would expect that a disproportionate number of students from the top $10 \%-25 \%$ of the graduating class of law schools outside New York State would take the New York bar exam instead of the plurality bar exam. ${ }^{124}$ This migration to New York would then reduce the average quality of those schools' graduates taking the local exam, at least as measured by class rank. Because law school grades are the single best predictor of bar exam performance, ${ }^{125}$ the lower average quality of the local bar exam group would presumably hurt the non-New York schools' local bar passage rate. Schools in New York, however, would be more likely to have more of the top 25\% of their graduating class taking the N.Y. bar exam. Of course, this could be offset by the large, strong outof-state bar exam-taking pool, which would increase the average quality of students taking the local bar and thus make it more difficult to pass. ${ }^{126}$

121. The scaled MBE cut score for New York is 134; the cut score is 132 in Illinois. See PMBR, MULTISTATE UPDATE (brochure published by a bar preparation company that specialized in MBE). New York also places more weight on non-MBE materials (60\% versus only $50 \%$ in Illinois), including a fifty-question multiple-choice section on N.Y. law. See BAR/BRI DIGEST 23,36 (2006)

122. In the 2006 edition, Chicago outscored NYU on most of the reported criteria, tied on one, and was outscored by NYU on only the undergraduate GPA numbers.

123. See supra note 107 (providing breakdown of Top 10 markets).

124. Since many of the non-New Yorkers taking the New York bar would be lawyers who had gotten jobs in New York, which is among the most desirable locations for large firm jobs, it seems likely that the New York bar takers would be disproportionately drawn from the higher ranks of their graduating classes. This perception is further reinforced by the disproportionate number of top law schools outside New York for which New York is the plurality bar exam, including seven among the sixteen non-New York schools ranked in the Top 20 (Yale, Harvard, Penn, Michigan, Duke, Georgetown, and George Washington.

125. See supra note 69.

126. We calculated the mean 200625 th percentile LSAT scores for each bar jurisdiction, weighted by average class size, for each law school sharing the same plurality bar exam. 
A third source of incommensurability is the practice in some states that permits candidates from non-ABA-accredited law schools, or candidates with only law office apprentice experience, to sit for the bar exam. The failure rate for these candidates is significantly higher than for applicants from $A B A$-accredited law schools. For example, California allows graduates of non-ABA-accredited law schools to take the bar exam (under certain conditions). In 2004, 2160 applicants fitting this profile took the California bar, but only $16 \%$ passed. In contrast, 8230 graduates of ABAaccredited law schools took the California bar, and $54 \%$ passed. ${ }^{127}$ Although several other states also allow non-ABA-accredited-school graduates to take the bar, only a handful of students do so in most states. ${ }^{128}$ The effect of the combination of the California bar rule, the large number of bar examinees from unaccredited law schools, and California's high cut score, is to significantly reduce the first-time bar passage rate (that is, the denominator in the bar passage statistic), thus giving most California schools a significant boost for the purposes of U.S. News rankings.

As shown in Table 9, the median bar passage scores are lower in lower tiers. However, there are several schools in Tiers 2,3, and 4 that have higher U.S. News bar input scores than at least one Top 16 law school. Because of the idiosyncrasies of the applicant pool for the California bar, where the overall first-time bar passage rate is reported as $61 \%$, five of the six highest bar input scores went to California law schools: Stanford (1.505), UCLA (1.410), UC Berkeley (1.372), UC Hastings (1.323), and USC (1.320). ${ }^{129}$ Another measure of the impact of the idiosyncrasies of bar exam

According to this (highly imperfect) measure of applicant pool quality, New York was ranked first (161.1) followed by Virginia (160.7), Utah (159.7), and Illinois (158.7). The jurisdictions with the weakest applicant pools, based on 25th percentile LSAT, were Wyoming (149.0), West Virginia (148.0), and South Dakota (147.0). It is worth noting that the 25th percentile LSAT statistics have climbed considerably in the last six years. In 2000, New York, Virginia, and Utah also had the strongest applicant pools, but with measurably lower numbers: 157.3, 157.1, and 155.3 , respectively.

127. Statistics, The Bar EXAMiner, May 2005, at 8 [hereinafter 2005 Statistics]. U.S. News reported a pass rate for California of $61 \%$, which is the first-time taker pass rate for the January and July exams. Unfortunately, the "source of legal education" information does not break down bar exam takers by first-time status. Id.

128. At least one non-ABA-accredited-law-school graduate took the bar exam in Alabama, Arizona, California, Colorado, Connecticut, D.C., Florida, Georgia, Idaho, Maine, Maryland, Massachusetts, Missouri, Nevada, New Hampshire, New Mexico, Pennsylvania, Tennessee, Texas, Vermont, Washington, West Virginia, and Wisconsin. Only in Alabama, California, Massachusetts, Tennessee, and Washington did more than $10 \%$ of the total number of bar takers come from non-ABA-accredited schools, however. The performance gaps in those states were Alabama, 50\%; California, 38\%; Massachusetts, 37\%; Tennessee, 25\%; and Washington, 2\%. This is the result of the Authors' calculations using data from 2005 Statistics, supra note 127, at 8-9.

129. Remarkably, the sixth school was Ave Maria (Tier 4), which claimed a $100 \%$ bar passage rate in a jurisdiction with a $74 \%$ first-time bar passage rate (resulting in a bar input score of 1.35). Because 2006 was the first year that Ave Maria was ranked by U.S. News, we could not compare this stellar performance to prior years. However, the Ave Maria Web site has posted 2003-2006 bar results for all Michigan law schools. According to these figures, Ave Maria has been number one in three of the last four years, posting perfect results in both 2004 and 2006. See Ave Maria School of Law, State of Michigan Bar Exam Results (July Exam), http://www.avemarialaw.edu/community/sharedFile/documents/MichiganBarResults2003to200 6JulyExam.pdf. 
results is the remarkable achievement of nineteen law schools that managed to post better bar passage scores than Marquette and University of Wisconsin, which enjoy $100 \%$ bar passage because of Wisconsin's diploma privilege for in-state graduates. ${ }^{130}$ Of these nineteen schools, sixteen had either California or New York as their plurality bar exam. ${ }^{131}$

Table 9. 2006 U.S. News Bar Passage Scores, by 2006 Ranking

\begin{tabular}{|l|c|c|c|c|c|}
\hline \multicolumn{1}{|c|}{ Rank } & Median & Minimum & Maximum & Range & Valid N \\
\hline Top 16 & 1.25 & 1.15 & 1.50 & 0.36 & $\mathrm{~N}=16$ \\
\hline Rest of Tier 1 & 1.13 & 1.02 & 1.32 & 0.31 & $\mathrm{~N}=34$ \\
\hline Tier 2 & 1.05 & 0.87 & 1.21 & 0.35 & $\mathrm{~N}=50$ \\
\hline Tier 3 & 0.98 & 0.72 & 1.19 & 0.47 & $\mathrm{~N}=36$ \\
\hline Tier 4 & 0.90 & 0.51 & 1.35 & 0.85 & $\mathrm{~N}=45$ \\
\hline
\end{tabular}

Obviously, the U.S. News bar passage score has too many extraneous and irrelevant factors that affect its calculation to transmit much useful information to prospective students. This is an unfortunate outcome for a population contemplating an investment of three years and $\$ 100,000$ or more in tuition and living expenses.

Our analysis offers little prescriptive advice for law schools trying to maximize their bar passage scores other than to reinforce the message that improving them is a good thing. Most law schools understand that bar passage is partially a function of high entering credentials and law school performance. There is already clear empirical evidence that many (if not most) law schools are placing more reliance on the LSAT for admission purposes. ${ }^{132}$ Over the last several years, law schools have also significantly increased the practice of flunking out low-performing students after the $1 \mathrm{~L}$ year. ${ }^{133}$ Presumably, this is done in the hope of boosting future bar exam results. We question the long-term institutional benefits of inducing additional fear and terror in a larger proportion of future alumni. There is also a certain irony in law schools, which specialize in the education of lawyers, failing to pursue curricular innovation or reform of the bar exam system as the first lines of defense to low bar performance. Law schools have ready access to information necessary to improve bar exam performance. ${ }^{134} \mathrm{We}$ are puzzled by why they do not make more use of it.

130. The Wisconsin schools do not have the maximum bar input score for U.S. News purposes because their pass rates are weighted by the $84 \%$ first-time passage for out-of-state graduates sitting for the Wisconsin bar.

131. Authors' calculations from our assembled datasets.

132. See supra note 67 , at 309-13, and accompanying text; supra note 126 (reporting that the 25th percentile LSAT score has jumped approximately four points since 2000).

133. See supra notes $74-83$ and accompanying text.

134. A fruitful line of inquiry might be research results reported by the LSSSE. See, e.g., LSSSE, ENGAGING LEGAL EDUCATION: MOVING Beyond THE STATUS QUo 11 \& n.1 (2007) (reporting that higher levels of faculty-student interaction resulted in self-reported gains in analytical ability, after controlling for LSAT scores, law school grades, gender, law school year, and race and ethnicity). 


\section{IMPROVING RANKINGS}

All rankings of legal education are imperfect as general measures of quality. ${ }^{135}$ The imperfections of the U.S. News survey are magnified by its status as the dominant measure of quality among important current and prospective students, alumni, and legal employers. Because these constituencies are too important to ignore, U.S. News affects behavior and resource allocation within law schools. Some commentators characterize this change as the onset of healthy competition, ${ }^{136}$ while law school deans are more likely to claim that U.S. News places them in the untenable position of choosing between "what is good for the law school and what is good for rankings." 137 In this part of the Article we suggest ways to improve rankings and improve the collective integrity of law schools and legal educators.

The solution is remarkably simple: Law schools should release more and better information into the public domain-information that would permit prospective students to realistically assess their post-graduation prospects for bar passage and type, range, and compensation of employment from each school they consider.

135. Several contributions to the recent Next Generation of Law School Rankings Symposium in the Indiana Law Journal made precisely this point. See, e.g., Scott Baker, Stephen J. Choi \& Mitu Gulati, The Rat Race as an Information-Forcing Device, 81 IND. L.J. 53,78 (2006) (acknowledging that "U.S. News doesn't accurately measure ... the quality of a legal education" but the fact that the rankings may be "imperfect, imprecise, or just plain bad" may be outweighed by the information-forcing effect the rankings have on law schools); Leiter, supra note 12, at 51 (discussing several valid and important ways to distinguish law school quality but noting that those measures "should be measured separately rather than aggregated on the basis of unprincipled and and unrationalizable schema"); Michael Sauder \& Wendy N. Espeland, Strength in Numbers? The Advantages of Multiple Rankings, 81 IND. L.J. 205, 213 (2006) (noting that because the process of rankings "magnif[ies] the importance of trivial differences, rankings change the phenomena that they purport only to measure"); Michael E. Solimine, Status Seeking and the Allure and Limits of Law School Rankings, 81 IND. L.J. 299, 303 (2006) (arguing that while the U.S. News may facilitate competition among law schools, the rankings themselves have become the measure of how the competition is won, thus stifling law schools' willingness to innovate in ways that will harm their U.S. News input measures); Stake, supra note 88, at 247-250 (providing various graphical depictions of how the process of ranking distorts distinctions between schools); see also Sauder \& Lancaster, supra note 65 (discussing problems of aggregating data into a single index).

136. See, e.g., Mitchell Berger, Why the U.S. News and World Report Law School Rankings are Both Useful and Important, 51 J. LEGAL EDUC. 487, 496-500 (2001) (arguing that U.S. News rankings supply students with relevant information such as law school reputation, bar passage rates, and faculty-student ratios, in a form that facilitates comparisons and that such information can "promote accountability and positive change" among law schools); Robert M. Lloyd, Hard Law Firms and Soft Law Schools, 83 N.C. L. REv. 667, 687 (2005) (arguing that "[j]ust as competition Hardened American business . . . the rankings have the potential to Harden law schools. Already, some law schools have started to impose discipline that would otherwise be unthinkable.").

137. Espeland \& Sauder, supra note 89, at $206 \&$ n.3 (quoting comments of one law school administrator during a qualitative study of rankings on U.S. law schools and acknowledging that faculty and administrators "consistently report[ed]" the pressure to make these trade-offs). 
The most prominent alternatives to U.S. News' rankings focus on scholarly prominence ${ }^{138}$ or output, ${ }^{139}$ which are criteria that are primarily of interest to law school faculty. As a result, they are an effective tiebreaker for prospective students admitted to a several elite law schools but do not offer guidance to students considering choices among non-elite schools. ${ }^{140}$ For an alternative ranking to affect law schools outside the elite ranks, it must "move the market" in the broad middle population of prospective students. We think the dominant position of U.S. News is largely due to high information costs faced by aspiring lawyers who are trying to make informed decisions on a three-year, six-figure investment. ${ }^{141}$ Our earlier work provided empirical evidence that law students choosing between non-elite law schools tend to discount U.S. News rank in favor attending a school that offers either lower tuition or proximity to a large and growing legal market. ${ }^{142}$ If law schools work collectivelyperhaps through mandatory guidelines of the American Bar Association or the American Association of Law Schools ${ }^{143}$ - to provide applicants with additional (and

138. See generally Brian Leiter, Measuring the Academic Distinction of Law Faculties, $29 \mathrm{~J}$. LEGAL STUD. 451 (2000); Leiter's Law School Rankings, http://www.leiterrankings.com.

139. See, e.g., Bernard S. Black \& Paul L. Caron, Ranking Law Schools: Using SSRN to Measure Scholarly Performance, 81 IND. L.J. 83 (2006) (unveiling law school rankings based on number of papers and downloads from the Social Science Research Network); Tracey E. George, An Empirical Study of Empirical Legal Scholarship: The Top Law Schools, 81 IND. L.J. 141 (2006) (ranking schools based on proportion of faculty with graduate degrees in the social sciences and various measures of output of empirical legal scholarship).

140. Most of the academic energy that goes into formulations of alternative rankings tends to omit roughly three-quarters of all schools. One prospective student wrote in a comment to a ranking post on a blog run by law professors that virtually all of the analysis was limited to highly ranked schools:

I am having to make a decision once $\&$ for all between St. Mary's Univ. and Texas Wesleyan Univ.... yes, I realize, not the most earth shattering decision-- both 4th tier, etc- who cares, -- however, this is quite likely an excessively important decision for my life, so Im trying desperately to get a finite, qualitative answer as to which is the bottom line "better" school.

Posting of Dan Filler to Concurring Opinions, http://www.concurringopinions.com/archives/ 2006/04/us_news_law_sch.html (Apr. 3, 2006, 01:00).

141. The annual anti-ranking letter signed by the majority of law school deans from ABAapproved law school seems to reflect a similar sentiment: "Rankings generate huge hype .... Applicants need help in widening their knowledge of schools that may be right for them, not narrowing their choices according to a ranking system." Deans Speak Out, supra note 7.

142. See Henderson \& Morriss, supra note 18, at 187-90.

143. We concede that a massive collective action problem hinders our solution-that is, a law school that provides more (unflattering) data in an environment of endemic gaming is going to get clobbered. This problem can be solved by an honest regulator or an accrediting agency that (a) imposes uniform guidelines and (b) has credible enforcement authority. $C f$. William D. Henderson \& Andrew P. Morriss, Rank Economics, AM. LAW., June 1, 2007, http://www.law.com/jsp/PubArticle.jsp?id=900005482655 (arguing that "law schools and the $\mathrm{ABA}$ have failed to adopt effective self-regulation" and suggesting several ways that the ABA could improve law school accountable through uniform standards and greater information transparency) (subscription required). 
more reliable) ${ }^{144}$ information on outcomes, the grip of U.S. News will be further loosened. ${ }^{145}$

Since 1990, U.S. News has, in the various permutations of its ranking methodology, relied on four different types of data that directly affect post-graduation outcomes: (1) employer interviews; (2) starting salaries; (3) employment rates (at graduation and three/six/nine months); and (4) bar passage rates. ${ }^{146}$ All of this information is relevant for prospective lawyers. Unfortunately, the first two, interviews and salaries, are no longer available to the public at the individual law school level. The third, employment statistics, are not broken down by legal versus non-legal employment and otherwise appear to be inflated and unreliable. ${ }^{147}$ And despite the availability of the fourth factor, bar passage, its value as a competitive metric is obscured by large jurisdictional differences in applicant pools and cut scores. ${ }^{148}$ Without meaningful access to these key data, prospective students inevitably rely upon U.S. News as a proxy for the things they care about. ${ }^{149}$ U.S. News has spurred law schools to release some data in a form that enables prospective students and legal employers to compare schools. ${ }^{150}$ Law schools could improve on this by releasing more data.

Consider a two-part thought experiment: First, how would prospective students respond if they had detailed school-level data on the volume and types of employer oncampus interviews; starting salaries of recent graduates; reliable employment rates, broken down by legal and non-legal employment; and bar performance, controlling for entering credentials and differences in cut scores? Second, how would changes in student preferences affect the behavior of law schools and legal employers? Although we think many law schools would be jarred by the ensuing competitive pressures, it is hard to imagine how law students would be made worse off.

144. See supra text accompanying notes 58-61 (expressing doubt about the veracity of employment figures reported to U.S. News).

145. Whether an alternative could compete with U.S. News in terms of brand name and distribution is a fair question. Alternative rankings might be sponsored by other media (for example, the Wall Street Journal, Financial Times, or Business Week - all of whom rank M.B.A. programs) or gain prestige by developing a reputation (for example, the Leiter Law School Reports).

146. See supra Table 1, p. 7.

147. See supra text accompanying notes $58-61$.

148. For a cogent discussion of the disparate range of cut scores as "federalism run amok," see Gary S. Rosin, Unpacking the Bar: Cut Scores, MBE Scaling, the LSAT, and Law School Bar Passage, Conference on Empirical Legal Studies, Austin, TX, (Poster Session, Oct. 27-28, 2006) ("With such a broad range of state Bar passage rates and the recent flurry of cut-score increases, it is easy to understand how some might consider state Bar admissions to represent federalism run amok. At root, these concerns call into question the quality of the stewardship of the states over admission to practice law."), revised version available at http://papers.ssrn.com/sol3/papers.cfm?abstract_id=914224.

149. Cf. Korobkin, Harnessing the Positive Power, supra note 1, at $40-44$ (observing that the rankings are primarily a market-clearing device that enables top law students and legal employers to identify each other, thus augmenting "employment opportunities and . . . longterm earning potential" for prospective law school applicants).

150. Cf. Baker et al., supra note 135, at 78 ("Before U.S. News, most law schools did not share information about faculty scholarship and hiring, the bar-passage rate and employment status of recent graduates, the number of books in their libraries, or student-faculty ratios."). 
The following three sections summarize this alternative vision. Section A discusses the impact of interview data. Section B combines employment and salary information. Finally, Section $\mathrm{C}$ focuses the importance of the bar exam and suggests a solution to the jurisdictional commensurability problem.

\section{A. Interviews}

The type and volume of employers visiting a law school for on-campus interviews (OCI) is valuable information to a prospective student, as it signals market demand for a school's graduates. Factors that clearly influence OCI activity include: (1) high ranking in U.S. News (Tier 1 or Top 16 status), (2) geographic proximity to large corporate law markets, (3) law school size, and (4) status as a historically black law school. ${ }^{151}$ If a student compared schools based on this data, the top nationally ranked law schools will continue to rank highly. Yet, schools ranked lower in U.S. News but located in large metropolitan areas will likely be cast in a more favorable light, as will historically black law schools and, possibly, other institutions with large minority enrollments. Similarly, many prospective employers may take notice of the paucity of firms (their competitors) at geographically remote law schools with strong students bodies.

For example, Table 10 shows that among the nine schools in the 2006 U.S. News rankings with a 25 th percentile LSAT score of 160 , there is wide dispersion in the amount of OCI activity among NALP employers (normalized by $1 \mathrm{~L}$ class size). This gap, which is a factor of five between William \& Mary and the University of Alabama, suggests the potential for a significant arbitrage opportunity that could produce a higher yield of desirable job candidates.

151. See supra note 113 and accompanying text; see also Henderson \& Morriss, supra note 18, at 189-90 (discussing regression results of Am Law $200 \mathrm{OCI}$ activity). 
Table 10. OCI Activity of Law Schools with 16025 th percentile LSAT, 2006 U.S. News

\begin{tabular}{|c|l|c|c|c|}
\hline $\begin{array}{c}\text { US News } \\
\text { Rank }\end{array}$ & \multicolumn{1}{|c|}{ Law Law School } & $\begin{array}{c}\text { 25th } \\
\text { Percentile }\end{array}$ & $\begin{array}{c}75 \\
\text { Percentile }\end{array}$ & $\begin{array}{c}\text { 2005 NALP } \\
\text { OCI Activity }\end{array}$ \\
\hline 27 & William \& Mary & 160 & 165 & 1.02 \\
\hline 43 & University of Colorado & 160 & 164 & 0.61 \\
\hline 43 & UC Hastings College of the Law & 160 & 164 & 0.59 \\
\hline 43 & American University & 160 & 163 & 0.35 \\
\hline 65 & Loyola (Los Angeles) Law School & 160 & 163 & 0.29 \\
\hline 65 & University of San Diego & 160 & 164 & 0.24 \\
\hline 58 & Temple University & 160 & 163 & 0.22 \\
\hline 80 & University of Richmond & 160 & 163 & 0.20 \\
\hline 43 & University of Alabama & 160 & 164 & 0.19 \\
\hline
\end{tabular}

Most large- and medium-sized legal employers, including many government agencies and non-profit organizations, are members of the National Association of Legal Placement (NALP). Each year, NALP compiles and publishes a form for each member-employer listing dozens of characteristics for prospective employees, including $\mathrm{OCI}$ activities at specific law schools. ${ }^{152}$ If its members agreed, NALP could aggregate this information at the law school level and publish it annually on its Web site. Ideally, the published data would include breakdowns by geographic area and employer type. In turn, this data could be used to generate a meaningful list of schools providing the most career opportunities for students. Because the infrastructure for this information is already in place, a modest fee for downloading (in spreadsheet format) would probably pay for the associated costs. ${ }^{153}$

We think that the publication of these results would change law school behavior for the better. Every law school would have a strong incentive to maximize the number of employers recruiting at their campus. Presumably, law school administrators would tout the quality of their student body to prospective employers. But they might also emphasize curricular innovations that add value beyond the presumption of "good quality in, good quality out." 154 Indeed, a dialogue between employers and law schools could become a source of innovation or institutional alliance. For example, law schools might be willing to offer new (and labor-intensive) skill-based courses in exchange for agreements to interview a set number of students or a cash payment to underwrite the development of the new program. Legal employers might agree to help develop and fund such programs in return for enhanced access to students. This type of competition would be harder to game, focusing competition in areas that would benefit students and employers.

152. This was the source of our data, which we painstakingly compiled with the help of research assistants.

153. U.S. News already charges a small fee for "premium" access to its rankings data, suggesting that such a fee is viable.

154. See supra note 109 and accompanying text. 


\section{B. Salary and Employment Information}

Although on-campus interviews are an important source of legal employment for many law schools, the majority of law students obtain permanent jobs through other means. ${ }^{155}$ For the class of 2003 , approximately two-thirds of students were offered employment before graduating law school. ${ }^{156}$ For students interested in employment in smaller firms, the public sector, or non-profit sector work, jobs are more commonly secured through traditional search methods, such as job postings, referrals, or selfinitiated contacts with employers. ${ }^{157}$ In many cases, offers are not received until after the bar results, in part because many of these employers are willing to hire only lawyers with licenses. ${ }^{158}$

The market for entry-level lawyers has important school-specific dynamics. ${ }^{159}$ Prospective law students would likely be interested in historical data on graduation rates, types of employment, geographic dispersion, and starting salaries of graduates of specific law schools. Drawing upon a detailed annual survey submitted by the law schools, NALP already collects and compiles this information for its annual Jobs \& $J D$ 's: Employment and Salaries of New Law Graduates series. ${ }^{160}$ Unfortunately these data are not available to the public as school-level data. Instead, the only publicly available school level data are the employment rates submitted to the ABA and U.S. News, which aggregate all types of jobs (including non-legal work) into a single employment rate, as if all jobs represented equal or commensurable outcomes. Further, even though the NALP survey typically contains information on approximately $92 \%$ of each year's graduates, ${ }^{161}$ the response rate varies dramatically by individual law schools. The relative size of the non-respondent pools can dramatically skew the data and thus provide a misleading (and likely inflated) impression of an applicant's eventual odds of obtaining gainful legal employment. ${ }^{162}$

155. James G. Leipold, After the Bar Exam: Legal Employment Trends For Law School Graduates, THE BAR EXAMINER, May 2005, at 28, 34 (reporting that, according to the Executive Director of NALP, "'[i]n 2003, just under one quarter of all jobs were obtained through the fall $\mathrm{OCI}$ process, and the vast majority were with large law firms").

156. Id.

157. Id.; see AFTER THE JD, supra note 16, at 82 \& fig. 11.2, tbl.11.2 (showing relative importance of various methods of finding a first job after law school).

158. See Leipold, supra note 155 , at 34.

159. See AFTER THE JD, supra note 16, at 80-82 \& fig.11.2, tbl.11.2 (summarizing how job search varies dramatically by relative rank of law school).

160. See Press Release, NALP, Market for New Law Graduates Up - Approaches $90 \%$ for First Time Since 2001 (July 18, 2006), available at http:/www.nalp.org/press/details.php?id=61 (reporting on the 32nd consecutive report of detailed demographic, employment, and salary information, which was drawn from 178 ABA-accredited law schools, who "provid[ed] employment information on $92 \%$ of all graduates of the Class of 2005"); Press Release, NALP, Market for New Law Graduates Is Steady (July 15, 2006), available at http://www.nalp.org/press/ details.php?id=55 (providing similar summary for class of 2004).

161. See NALP Press Releases, supra note 160.

162. Although the $A B A-L S A C$ Official Guide to Law Schools reports the number of graduates whose employment status is unknown, its percentage breakdowns by sector are based on the number of known respondents. "Hence," the Official Guide cautions, "for the schools reporting a large percentage of graduates for whom the employment status is unknown, the percentage 
Law schools, acting through their accrediting agency, the ABA, could authorize NALP to compile and publish school-level salary and employment information. Providing information on the distribution of salaries of recent graduates would, for example, allow students a realistic method of comparing their expected debt levels to their ability to pay off student loans after graduation. ${ }^{163}$ Salaries have the potential to exert a large anchoring effect on law student expectations; furthermore, average salaries can be substantially affected by a small fraction of students obtaining lucrative large firm employment. Therefore, a more useful and accurate summary of information would provide a detailed breakdown of employment type by law schools. However, even the existing NALP salary data could be useful for students contemplating the enormous time and expense of a legal education today.

By disclosing school-specific information by both employment type and expected salary, law schools would give prospective students the information to carefully weigh the path dependencies of electing to go to a more elite (and expensive) law school. This may induce a healthy interaction between desired employment options and price. For example, schools differ in their success rates at placing students in prosecutors' offices, federal and state government agencies, judicial clerkships of various types, small firms, large firms, non-profit sector employers, and other distinct markets. Thus, if a student has aspirations toward criminal prosecution or non-profit work, he or she might be attracted to a more affordable, lower ranked law schools that has a strong record of placing students in these practice areas in the geographic region where he or she wishes to live. Armed with such information, prospective students would be better informed about the type of practice for which each potential school would be able to equip them. In fact, some law schools may find that the disclosure of detailed placement data may enable them to move more effectively toward a long-term niche strategy. ${ }^{164}$

Publishing reliable school-level information on employment types, employment rates, geographic placement, and salaries would inevitably lead to more price-sensitive shopping on the part of prospective students. This information would permit them to make more informed choices. Similarly, it would also push high-cost schools to justify their programs' additional costs to prospective students, making the market for legal education more competitive. Providing such information is obviously not in the best interest of all law schools-certainly, additional price pressure and comparison shopping would hurt some schools' budgets. ${ }^{165}$ But unwary students, who lack clear

reported may not be a very accurate reflection of the actual percentage of the class as a whole." ABA-LSAC Official GuIDE To LAW SchOOLS 72 (2008 ed.).

163. Moderate increases in starting salaries and the debt loads brought on by spiraling tuition are on a collision course. See, e.g., Jones, supra note 14 (reporting that the average cost of a legal education has increased $267 \%$ since 1990 , compared to a $60 \%$ rise in associate salaries working in private firms).

164. Cf. Rachel F. Moran, Of Rankings and Regulation: Are the U.S. News \& World Report Rankings Really a Subversive Force in Legal Education?, 81 IND L.J. 383 (2006) (noting the current rankings phenomenon is marked by gaming strategies rather than competitive innovation and marshaling a cogent argument that rigid one-size-fits-all $\mathrm{ABA}$-accreditation standards foster this stagnant climate).

165. Over the last few years, there has been a rapid proliferation in the number of new law schools. See Leigh Jones, Bar Exam Failures Are on the Rise, NAT'L L.J., Mar. 13, 2006, at 1, 16 (noting that "[s]ince 2003, at least seven new law schools have popped up across the country" and are in the process of getting provisionally approved by the ABA). A 
and comparable information on employment outcomes, are likely to have unrealistic expectations on the financial benefits of a legal education. Since our collective enterprise is made possible by their ability to borrow money against their future earnings, the legal academy has an obligation to ensure fair and accurate disclosure to prospective students.

\section{Bar Passage}

We think that bar passage is an important criterion on which students ought to be able to compare law schools before applying or accepting an offer of admission. We also think U.S. News deserves praise (rather than the usual brickbats) for attempting to produce a consistent means with which to measure bar exam success. However, the current bar passage input score provides virtually no guidance to prospective students.

Fortunately, law schools, acting in conjunction with the Law School Admission Council (LSAC) and the National Conference of Bar Examiners (NCBE), could implement a data pooling arrangement that could shed important light on law school's ability to prepare in graduates for the bar exam. Although there is a wide array of state bar exams with different substantive components, forty-eight states currently administer the Multistate Bar Examination (MBE), which is a 200-question multiplechoice exam covering contracts, constitutional law, criminal law and procedure, evidence, real property, and torts. ${ }^{166}$ Similarly, forty-seven states currently administer the Multistate Professional Responsibility Examination (MPRE), which is a fiftyquestion multiple-choice exam on legal ethics. With both exams, the examiners contend that the scaled scores are comparable across test administrations. ${ }^{167}$ Although each state sets its own cut score, scaled MBE and MPRE scores are comparable across jurisdictions. Ideally, MBE and MPRE scores could be combined with entering credential and demographic information from the LSAC.

The purpose of the data-pooling arrangement would be to create an ongoing data set that tracks law school performance on each of these standardized tests. In turn, these data could be used to generate school-specific bar results within certain bandwidths of entering credentials. ${ }^{168}$ This information could be published in table format or posted on the Web using an interactive design that permits direct comparisons among different law schools. Thus, if a particular law school provides a student with a statistically higher probability of achieving a target MBE score, ${ }^{169}$ that student may carefully consider trading down —or up—in relative prestige or paying higher tuition for a program associated with higher scores.

countervailing force, which we should consider, is letting inferior schools fail. Providing accurate and complete consumer information will expedite this process.

166. See 2005 Statistics, supra note 127 , at 37 (summarizing the MBE).

167. See id. at 37, 40. In contrast, the Multistate Performance Exam (MPT) and the Multistate Essay Exam (MEE), which are used by roughly half of the states, are graded by bar examiners for each state and are therefore not commensurable.

168. This type of large-scale analysis was actually done thirty years ago, before we had the benefit of advanced computers. See, e.g., Alfred B. Carlson \& Charles E. Werts, Relationshits among law School Predictors, law School Performance, And Bar EXAMINATION RESULTS (ETS 1976).

169. Among the forty-eight states requiring the MBE, the cut scores range from 120 to 145 on a 200-point scale. See PMBR, supra note 121. 
From the perspective of law schools, the perceived danger is that professors will "teach to the bar" and, thus, neglect materials that they believe are much more important to helping a student grow as a professional. ${ }^{170}$ For several reasons, this attitude can easily devolve into an excuse to avoid new and potentially more effective teaching methods. For example, findings from the 2006 Law School Survey of Student Engagement suggest that a higher level of faculty-student interaction, including prompt oral or written feedback and discussions outside of class, is associated with higher selfreported gains in analytical ability, which has traditionally been identified as the primary competency tested by the bar exam. ${ }^{171}$ In addition to the LSAT and law school grades, it is certainly reasonable to believe that the quality of law school instruction is also associated with higher bar scores.

In the end, we as law professors need to guard against our own elitist tendencies. ${ }^{172}$ Every year, approximately $25 \%$ of all bar applicants fail to pass the bar, including a disproportionate number of minority candidates. ${ }^{173}$ If law professors are not willing to compete to improve those outcomes or, alternatively, to meaningfully engage with state bar officials to formulate a better or more valid test, ${ }^{174}$ then perhaps it is time to articulate how we are serving our students and the public.

\section{CONCLUSION}

Like many rankings commentators, we share the general skepticism about the value of simple composite rankings. ${ }^{175}$ Nonetheless, we also think that rankings can play an important role in producing data that enable better competition in legal educationcompetition that will benefit law students. In particular, we think students can make use of data on outcomes, from bar examination results to interview data, to intelligently make choices about whether to apply to law school, about which law schools to apply to, and about which school to attend. If students had more reliable and inexpensive sources of such data-beyond what is available from U.S. News-there would be a healthier competition among law schools for students, competition that we think would result in reduced tuition opportunities for at least some students.

170. See, e.g., AALS Survey, supra note 74, at 455 (summarizing reactions of many law professors who worry about excessive emphasis on higher bar scores).

171. See Robert SteVENS, LAW SCHOOLS: Legal EdUCATION IN AMERICA FROM THE 1850 S TO THE 1980s (1983) (discussing controversies about the bar exam and reasons why it has endured).

172. See Randolph N. Jonakait, The Two Hemispheres of Legal Education and the Rise and Fall of Local Law Schools (N.Y. L. Sch. Pub. L. \& Legal Theory Res. Paper Series 05/06-29), available at $\mathrm{t}$ http://ssrn.com/abstract $=913084$ (questioning the agenda set by elite law schools where most law professors obtained their law degrees).

173. See, e.g., WIGHTMAN, supra note 69, at 27-32 (reporting large racial disparities in the LSAC Bar Passage Study for first time and eventual bar passage rates); STEPHEN P. KLEIN \&

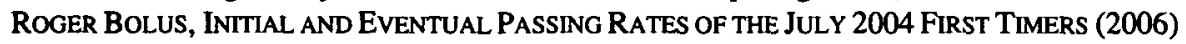
(reporting essentially the same results for the Texas bar population), available at http://www.ble.state.tx.us/announcements/klein\%20report\%200606.doc.

174. In other words, to do more than to gripe about bar exams around the coffee machine in the faculty lounge.

175. See supra note 12 . 
A final recommendation is to encourage research into the value of legal education. For example, a recent Journal of Applied Finance paper evaluated the impact of various types of degrees on success in the hedge fund industry. Using a proprietary dataset from an investment management firm on 147 hedge funds, which included 7820 monthly return observations, the study found that "managers from top-ranked schools emerge as significant contributors to fund performance," while "undergraduate economics and technical backgrounds from top-ranked schools emerge as significantly negative influences." 176 Studies of the impacts of various types of legal education on lawyers in different career paths could shed similar light on the value of legal education. In particular, such research could tell us whether particular types of legal education produce better outcomes. For example, clinical legal education is generally more expensive than the large Socratic or lecture classes that dominate many law schools' upper class curricula. Similarly, small sections are more expensive to operate than large sections. Are these extra costs worthwhile? Comprehensive research is necessary to answer such questions.

There are a number of encouraging indicators in this area. The AALS has recently decided to sponsor and assist in the development of data sets on important aspects of legal education. The LSSSE also provides in-depth data on student behavior in law school, which can be linked to outcome measures such as MBE scores, GPA, and placement data, to determine what works and what does not work in legal education. Taking a lesson from the Oakland Athletics' general manager, Billy Beane, who revolutionized baseball by applying statistical analysis to various aspects of the national pastime, ${ }^{177}$ a data-based assessment of all aspects of legal education seems to us to be the best response to the problematic aspects of the U.S. News's rankings.

176. Clark L. Maxam, Ehsan Nikbakht, Milena Petrova \& Andrew C. Spieler, Manager Characteristics and Hedge Fund Performance, 16 J. APP. FiN. 57, 69 (2006).

177. See supra note 98 and accompanying text. 